

\section{Sumário}

Dossiê TEMÁTICO: NOVOS INSTITUTOS JURÍDICOS DE LICITAÇÕES E CONTRATOS 17

I. LicitaÇõEs E CONTRATOS PÚBLICOS: PARTE GERAL. 18

INTEGRATED CONTRACT IN LAW 14.133/2021: NEW LAW, SAME PROBLEMS? A STUDY OF COMPARATIVE LAW .20

Paulo Afonso Cavichioli Carmona, Bruno Ribeiro Marques e Odilon Cavallari

Reajustamento de preços na Nova Lei de Licitações e Contratos Administrativos BRASILEIRA: O "Princípio" Da ANUALIDAde.

Ricardo Silveira Ribeiro e Bráulio Gomes Mendes Diniz

A nova Lei de Licitações, as encomendas tecnológicas e o diálogo competitivo .61 André Dias Fernandes e Débora de Oliveira Coutinho

LiCITAÇÕES, CONTRATOS E O IMPULSO À APRENDIZAGEM PROFISSIONAL: UM ESTUDO SOBRE A CONTRATAÇÃo de APRENDizes no ESTAdo do AMAZONAS, BRAsIL

Emerson Victor Hugo Costa de Sá, Natasha Yasmine Castelo Branco Donadon e Mauro Augusto Ponce de Leão Braga

Licitações, contratos e Modelo Brasileiro de Processo: notas sobre a viabilidade DA UTILIZAÇÃo DE FERRAMENTAS PROCESSUAIS PARA CONFERIR MAIOR EFICIÊNCIA ÀS AQUISIÇÕES PÚBLICAS

Claudio Madureira e Carlos André Luís Araujo

RESOlUÇão DE CONFLITOS COM A ADMINISTRAÇÃo PÚBLICA E A NOVA LEI DE LICITAÇÕES E CONTRATOS: REFORÇO DOS MEIOS ALTERNATIVOS.

Clarissa Sampaio Silva e Danille Maia Cruz

A Adesão do Brasil ao Acordo sobre Contratações Públicas da OMC: entre tabus e DIFICULDADES REAIS

Eduardo Ferreira Jordã e Luiz Filippe Esteves Cunha

II. Accountability e controle

A LEI N. ${ }^{\circ}$ 14.133/2021 E OS NOVOS LIMITES do CONTROLE EXTERNO: A NECESSÁRIA DEFERÊNCIA dos Tribunais de Contas em prol da Administração Pública .................................. 162 Ricardo Schneider Rodrigues

O CONTROLE DAS CONTRATAÇÕES PÚBliCAS E A NOVA LEI DE LICITAÇÕES: O QUE HÁ DE Novo? 183

Leandro Sarai, Flávio Garcia Cabral e Cristiane Rodrigues Iwakura 
Programa de compliance como exigênCia em licitações: ANálises EM Prol da QUALIFICAÇÃo DO PROCESSO LICITATÓRIO NO CONTEXTO DA LEI 14.133/2021.

Cristian Ricardo Wittmann e Anayara Fantinel Pedroso

A NOVA REALIDAde bRASILEIRA DE NECESSIDADE DE PROGRAMAS DE INTEGRIDADE DAS PESSOAS JURÍDICAS LICITANTES EM PROCESSOS LICITATÓRIOS DA ADMINISTRAÇÃO PÚBLICA 227

Fernando Silva Moreira dos Santos e Luiz Fernando de Oriani e Paulillo

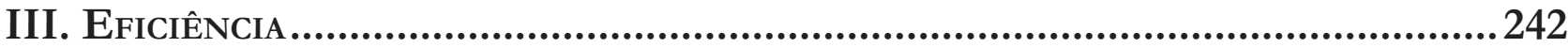

Efficiency contracts in the New Brazilian Procurement Law: conceptual FRAMEWORK AND INTERNATIONAL EXPERIENCE

Floriano de Azevedo Marques Neto, Hendrick Pinheiro e Tamara Cukiert

A gestão de riscos como instrumento para a aplicação efetiva do Princípio Constitucional dA EFICIÊNCIA.

Rafael Rabelo Nunes, Marcela Teixeira Batista Sidrim Perini e Inácio Emiliano Melo Mourão Pinto

IV. Contratação PÚblica No Direito ESTrangeiro

LA ADQUisición de VACUNAS CONTRA LA COVID-19 POR COLOMBIA: ENTRE LA CONFIDENCIALIDAD Y LA FALTA DE TRANSPARENCIA. 284

Gressy Kareny Rojas Cardona e David Mendieta

LA DISCRIMINACIÓN EX POST DE LOS OFERENTES DE UNA LICITACIÓN PÚBLICA COMO INFRACCIÓN ADMINISTRATIVA Y DE LIBRE COMPETÊNCIA 312 Jaime Arancibia Mattar

LA DISCRIMINACIÓN EX POST DE LOS OFERENTES DE UNA LICITACIÓN PÚBLICA COMO INFRACCIÓN ADMINISTRATIVA Y DE LIBRE COMPETÊNCIA..........................................................332 Udochukwu Uneke Alo, Obiamaka Adaeze Nwobu e Alex Adegboye

Outros Temas 348

I. Políticas públicas e institucionalidade

¿Existe El derecho humano a la identidad Cultural de los Migrantes en El Derecho INTERNACIONAL? 351 Juan Jorge Faundes e Glorimar Alejandra Leon Silva

El acceso a la justicia y el debido proceso ante el Tribunal Constitucional y la CorTe Suprema: dos NOCIONES DEL CONTENCIOSO ADMINISTRATIVO CHILENO .384 Pedro Harris Moya 
“Ministrocracia” E DECISÕES INDIVIDUAis CONTRAditórias No Supremo Tribunal FEDERAI

Ulisses Levy Silvério dos Reis e Emilio Peluso Neder Meyer

A POlÍtica de INOVAÇÃo COMO INSTRUMENTO DE REDUÇÃo DAS DESIGUALDADES REGIONAIS NO BRASIL

Caroline Viriato Memória e Uinie Caminha

Conflitos de Competência E A JudicializaÇão da Saúde no Federalismo Brasileiro.447 Jorge Leal Hanai, Luis Antônio Abrantes e Luiz Ismael Pereira

O Ministério Público no enfrentamento dos Reflexos da CRise da Covid-19: UMA

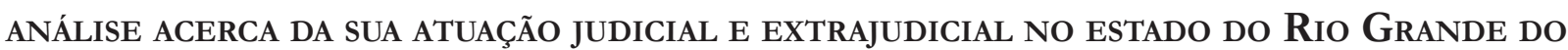
NorTE

Raquel Maria da Costa Silveira, Ana Mônica Medeiros Ferreira, Flávio Luiz Carneiro Cavalcanti e Haroldo Helinski Holanda

A CONSAgRaÇão CONSTITUCIONAL DA POlítica FALIMENTAR

Nuno de Oliveira Fernandes

II. Políticas públicas, grupos vulneráveis e litígios estruturais

LAS LIMITACIONES A LOS DERECHOS DE LOS GRUPOS VULNERABLES Y LOS SUJETOS DE ESPECIAL PROTECCIÓN DURANTE LA PANDEMIA Mary Luz Tobón Tobón

LitígIOS ESTRUTURAIS E A PROTEÇÃO DOS DIREITOS DOS POVOS INDÍGENAS DURANTE A PANDEMIA DE Covid-19: CONTRIBUições do ICCAL

Ana Carolina Lopes Olsen e Bianca M. Schneider van der Broocke

EPISTEMICÍDIO DAS NARRATIVAS NEGRAS E LITÍGIO ESTRUTURAL: INSTRUMENTOS EXTRAJUDICIAIS PARA DISSOLUÇÃO DO PROBLEMA NO SISTEMA EDUCACIONAL .......................................582

Vitor Fonsêca e Caroline da Silva Soares

Trajetórias E DiRETRIZES dAS POlíticas PÚbliCAS NACIONAIS PARA A POPULAÇão INFANTOJUVENIL EM SITUAÇÃO DE RUA...

Wânia Cláudia Gomes Di Lorenzo Lima, Cynthia Xavier de Carvalho e Maria Creusa de A. Borges

Emprendimiento como Fuente de Ingresos para las Víctimas del Conflicto Armado en el Marco de la Ley 1448 de Colombia. Reflexiones de la Implementación en el Valle del Cauca

Saulo Bravo García e Luz Marina Restrepo García

III. Políticas públicas e aÇão Restaurativa. 
JUSTIÇA RESTAURATIVA COMO AÇÃO COMUNICATIVA: EQUILÍBRIO ENTRE SISTEMA E MUNDO DA

Daniela Carvalho Almeida da Costa e Luciana Leonardo Ribeiro Silva de Araújo

JUSTIÇA RESTAURATIVA: ACORDOS E COOPERAÇÃO.................................................668

Samyle Regina Matos Oliveira e Selma Pereira de Santana 


\title{
Licitações, contratos e Modelo Brasileiro de Processo: notas sobre a viabilidade da utilização de ferramentas processuais para conferir maior eficiência às aquisições públicas*
}

\author{
Bidding, contracts and Brazilian Process \\ Model: notes on the feasibility of utilising \\ procedural tools to provide greater efficiency to \\ public procurement
}

Claudio Madureira**

Carlos André Luís Araujo***

* Recebido em 16/09/2021

Aprovado em 14/01/2022

Este trabalho se associa ao Grupo de Pesquisa Fundamentos do Processo Civil Contemporâneo (integrante da PROCNET, Rede Internacional de Pesquisa sobre Justiça Civil e Processo Contemporâneo), ao Laboratório de Processo e Constituição do Programa de Pós-Graduação em Direito da Universidade Federal do Espírito Santo (LAPROCON-PPGDI-UFES) e à linha de pesquisa Sistemas de Justiça, Constitucionalidade e Tutelas de Direitos Individuais e Coletivos, do mesmo Programa de Pós-Graduação, com área de concentração em Justiça, Processo e Constituição, que assume como objetivo geral a estruturação do processo como meio adequado de garantia dos direitos fundamentais erigidos em estatura constitucional e traz entre os seus objetivos específicos a pesquisa dos fundamentos de hermenêutica jurídica voltados aos conceitos de teoria da norma por meio do crítica e do estudo dos diversos conceitos de justiça.

** Doutor em Direito pela PUC/SP, Mestre em Direito Processual pela UFES, Professor Adjunto do Departamento de Direito da UFES, com atuação nos Cursos de Graduação e Mestrado, Procurador do Estado do Espírito Santo e Advogado.

Email: professorclaudiomadureira@gmail.com

*** Mestrando em Direito Processual pela UFES, Procurador do Município de Ibiraçu/ ES e Advogado.

Email: araujo.carlosandreluis@gmail.com

\section{Resumo}

Este artigo tem por objetivo demonstrar que o rigor procedimental a que em geral se atribui a ineficiência das licitações/contratações públicas pode ser flexibilizado, de modo a produzir eficiência, mediante utilização de soluções típicas do Direito Processual. Analisamos os textos normativos disponíveis e fizemos cuidadosa revisão da literatura jurídica (fontes). Posteriormente, conjugamos a doutrina da processualidade no Direito Administrativo à compreensão (inerente a ela e à doutrina do formalismo-valorativo) de que o processo se diferencia do procedimento por se qualificar como procedimento em contraditório (método), demonstrando que as licitações/contratações públicas se apresentam, com base na Lei n. ${ }^{\circ}$ 14.133/2021, como autênticos processos administrativos, e que essa especificidade do seu regime normativo abre campo para a utilização de ferramentas próprias do Modelo Brasileiro de Processo para superar a referida rigidez procedimental (resultados). A pesquisa não comporta limitações de ordem prática (porque todas as fontes consultadas estavam disponíveis) ou teórica (porque dialoga com publicações anteriores) relevantes. Além disso, ela tem implicações sociais importantes. Afinal, se é verdade que o rigor procedimental incidente nesse contexto pode comprometer a eficiência das aquisições públicas, também é certo que a atividade administrativa realizada nas licitações e contratos da Administração não pode prescindir de um mínimo rigor procedimental, sem o qual seria inviável o exercício da atividade de controle administrativo que possibilita a prevenção de atos de corrupção e da malversação de recursos públicos. Disso resulta o valor e a originalidade da sua contribuição para o desenvolvimento da Ciência, inclusive para efeito de fomentar pesquisas futuras sobre a utilização de ferramentas processuais que promovam eficiência às aquisições públicas.

Palavras-chave: Licitações; Contratos; Eficiência; Ferramentas processuais. 


\section{Abstract}

This article aims to demonstrate that the procedural rigour to which in general the inefficiency of public biddings/contracts is attributed can be made more flexible, in order to produce efficiency, through the use of typical solutions of Procedural Law. We analysed the available normative texts and carefully reviewed the legal literature (sources). After that, we combine the doctrine of the processualism in Administrative Law with the understanding (inherent to it and to the doctrine of formalism-valuative) that the process differs from the procedure because it is developed in contradictory terms (work method), demonstrating that public biddings/contracting are presented, under the aegis of Law No. 14,133/2021, as authentic processes administrative, and that this specificity of its normative regime opens the field for the use of tools specific to the Brazilian Process Model to seek to overcome this procedural rigidity (results). The research does not include relevant practical (because all sources consulted were available) or theoretical (because it dialogues with previous publications) limitations. In addition, it has important social implications. After all, if it is true that the procedural rigidity incident in this context can compromise the efficiency of public biddings, it is also certain that administrative activity carried out in bids and contracts of the Administration cannot do without a minimum of procedural rigids, without which it would be unfeasible to exercise the administrative control activity that allows the prevention of acts of corruption and the misappropriation of public resources. Hence its contribution to foster future research on the use of procedural tools that promote efficiency of public biddings.

Keywords: Bidding; Contracts; Efficiency; Process tools.

\section{Introdução}

Temos uma nova lei de licitações e contratos, aprovada pelo Congresso Nacional em dezembro de 2020 e sancionada pela Presidência da República em abril de 2021: a Lei n. ${ }^{\circ}$ 14.133. A novatio legis revoga a Lei n. ${ }^{\circ}$ 8.666/1993, a Lei do Pregão (Lei n. $\left.{ }^{\circ} 10.520 / 2002\right)$ e parte da Lei do Regime Diferenciado de Contratações (Lei n. ${ }^{\circ}$ 12.462/2001) ${ }^{1}$, além de introduzir modificações no Código de Processo Civil de 2015, no Código Penal, na Lei Geral de Concessões (Lei n. ${ }^{\circ}$ 8.987/1995) e na Lei das Parcerias Público-Privadas (Lei n. ${ }^{\circ}$ 11.079/2004). A sua edição resulta, destarte, de iniciativa do Parlamento por procurar consolidar a disciplina normativa do tema em um único diploma legal, aplicável tanto à União Federal quanto aos Estados, ao Distrito Federal e aos Municípios, porque editado, considerando-se o disposto no inciso XXVIII do artigo 22 da Constituição da República², como norma geral em matéria de licitações e contratos.

Também a Lei n. ${ }^{\circ}$ 8.666/1993 foi editada, a seu tempo, como lei geral voltada à centralização da disciplina jurídica das licitações e contratações públicas. Porém, com o decorrer dos anos o seu texto passou a ser aplicado concomitantemente com outros diplomas legais, com destaque para a incidência da Lei Geral

\footnotetext{
1 Esses diplomas normativos (Lei n. ${ }^{\circ}$ 8.666/1993, Lei n. ${ }^{\circ}$ 10.520/2002 e parte da Lei n. ${ }^{\circ}$ 12.462/2011) apenas permanecem incidentes, nos dois anos seguintes, por força de regra de transição instituída pelo legislador no artigo 191, do que resulta, ainda, a previsão, no inciso II do seu artigo 193, de eles estarão revogados “após decorridos 2 (dois) anos da publicação oficial” da Nova Lei Geral de Licitações e Contratos. Deve estar claro, contudo, que o legislador não estabeleceu período de vacatio legis para a vigência da Lei n. ${ }^{\circ}$ 14.133/2021, mas apenas admitiu, como regra de transição, que "até o decurso do prazo de que trata o inciso II do caput do art. 193, a Administração" opte "por licitar ou contratar diretamente de acordo com" o seu texto "ou de acordo com as leis citadas no referido inciso" (Lei n. ${ }^{\circ}$ 8.666/1993, Lei n. ${ }^{\circ}$ 10.520/2002 e parte da Lei n. ${ }^{\circ} 12.462 / 2011$ ), com as ressalvas de que "a opção escolhida deverá ser indicada expressamente no edital ou no aviso ou instrumento de contratação direta" e de que é "vedada a aplicação combinada" da novatio legis com os referidos atos legislativos.

2 CRFB. "Art. 22. Compete privativamente à União legislar sobre: [...] XXVII - normas gerais de licitação e contratação, em todas as modalidades, para as administrações públicas diretas, autárquicas e fundacionais da União, Estados, Distrito Federal e Municípios, obedecido o disposto no art. 37, XXI, e para as empresas públicas e sociedades de economia mista, nos termos do art. $173, \$ 1^{\circ}$, III” (Redação dada pela Emenda Constitucional no 19, de 1998).
} 
de Concessões, da Lei do Pregão, da Lei do Regime Diferenciado de Contratações, da Lei das Parcerias Público-Privadas e da Lei das Estatais (Lei n. ${ }^{\circ}$ 13.303/2016), que foram aprovadas para resolver problemas específicos surgidos no ambiente administrativo, mas indiciam, quando analisadas conjuntamente, o envelhecimento de soluções concebidas pelo legislador há quase três décadas. Na prática, a despeito da sua gradativa atualização por leis esparsas, o regime normativo revogado enfrentava questionamentos por parte de governantes, de gestores/servidores/empregados públicos que atuam na realização de licitações e na formalização/execução de contratos administrativos (contratantes) e de fornecedores do poder público (licitantes/contratados).

É nota comum no imaginário de contratantes e licitantes/contratados a crítica à rigidez do regime normativo pretérito, à consideração de que ele engessava a atividade administrativa, a ponto de criar embaraços à concepção de soluções criativas tendentes a otimizar procedimentos e reduzir custos. Porém, mesmo concordando quanto a esse aspecto, contratantes e licitantes/contratados em geral apontam razões distintas para a origem do problema. Incomodam os contratantes as dificuldades que resultam do enrijecimento procedimental imposto pela legislação revogada à realização das licitações e à formalização/execução dos contratos, enquanto licitantes/contratados se ressentem da positivação em favor da Administração de prerrogativas processuais (também chamadas cláusulas exorbitantes) que do seu ponto de vista afetariam a segurança jurídica nas relações entre o poder público e seus fornecedores, tornando as prestações licitadas/ contratadas artificialmente onerosas.

A despeito dos problemas que gera, o rigor formal adotado nas licitações e contratações públicas (que supõe a centralização das decisões adotadas na própria Administração, a suscitar, inclusive, o estabelecimento das cláusulas exorbitantes que a beneficiam) fazparte do jogo. Afinal, recobrando a conhecida lição de Cirne Lima, administrar, na esfera pública, "é a atividade do que não é proprietário, do que não tem a disposição da cousa ou do negócio administrado" 3 . Por isso a atividade administrativa, inclusive aquela desempenhada no contexto da realização de licitações e da formalização/execução de contratações públicas, é submetida a rígido controle, realizado, quer no âmbito interno da Administração, onde é exercitado diretamente pelas controladorias e pela Advocacia Pública e de forma difusa pelos demais agentes estatais, quer como atividade de controle externo, contexto em que é desempenhado pelo Ministério Público, pelos Tribunais de Contas e pela própria sociedade, quando impugna a validade de atos praticados em sede administrativa e judicial. Assim, não vemos sentido em propor, pelo menos em um trabalho jurídico, que a resolução do problema passa pelo afastamento/desconsideração da rigidez conferida pelo legislador ao procedimento empregado nas licitações e contratações públicas.

Disso decorre a nossa opção por enfrentá-lo sob perspectiva distinta, aderente ao método aplicado às pesquisas realizadas no âmbito da Ciência do Direito, que toma como objeto de análise as regras e princípios que compõem o ordenamento, e que por isso não admite a formulação de hipóteses teóricas tendentes à subversão dos seus conteúdos ${ }^{4}$. Feito esse corte metodológico, dedicamo-nos a investigar se o problema po-

${ }^{3}$ LIMA, Rui Cirne. Princípios de direito administrativo. 6. ed. São Paulo: Revista dos Tribunais, 1987. p. 22.

${ }^{4}$ O objeto de análise da Ciência do Direito são as normas (regras e princípios) que compõem o ordenamento. KELSEN, Hans. Teoria pura do direito. 7. ed. São Paulo: Martins Fontes, 2006. p. 79-119. Podendo ser estendido, ainda, ao modo como essas regras e princípios são aplicados. Sobre o assunto, REALE, Miguel. Lições preliminares de direito. 24. ed. São Paulo: Saraiva, 1998. p. 64-65; FERRAZ JUNIOR, Tércio Sampaio. Teoria da norma jurídica: ensaio de pragmática na comunicação normativa. 4. ed. Rio de Janeiro: Forense, 2009. p. 114; DINIZ, Maria Helena. Compêndio de introdução à ciência do direito: introdução à teoria geral do direito, à filosofia do direito, à sociologia jurídica e à lógica jurídica: norma jurídica e aplicação do direito. 20. ed. São Paulo: Saraiva, 2009. 198-199; MADUREIRA, Claudio. A ciência jurídica e sua função social. Derecho y Cambio Social, v. 42, p. 01-12, 2015. Disponível em: http:// www.derechoycambiosocial.com/revista042/A_CIENCIA_JURIDICA_E_SUA_FUN\%C3\%87AO_SOCIAL.pdf Acesso em: 01 set. 2021. Nesse sentido, eventual crítica ao texto normativo aprovado pelo Parlamento (por exemplo para efeito de afirmar que o legislador foi tímido quanto a certo ponto da norma construída, ou que não concebeu a melhor solução normativa para a resolução dos problemas enfrentados) soaria como desrespeito, ou abandono, por parte do pesquisador, ao seu objeto de análise. Esse tipo de crítica seria adequado, por exemplo, em trabalhos construídos no âmbito da Ciência Política, que têm por objeto de análise é a atividade desenvolvida pelo Parlamento. Todavia, a admissibilidade da sua inserção em trabalhos jurídicos corresponderia a aceitar, mutatis mutandi, que pesquisadores do campo da Biologia pudessem se valer da sua Ciência para criticar a natureza (por exemplo, para dizer que a grama 
deria ser solucionado (ou, quando menos, ter os seus efeitos minimizados) mediante reformulação do modo como os processos de licitação e de contratação pública são conduzidos pela Administração. Em específico, desejamos induzir a compreensão de que o rigor procedimental que os caracteriza pode ser flexibilizado nos casos concretos, de modo a produzir eficiência, mediante utilização de ferramentas próprias do Modelo Brasileiro de Processo.

\section{Notas sobre a doutrina da processualidade do direito administrativo}

Em rigor, não há muita novidade nessa proposta teórica, há muito sustentada, no plano da Ciência, por autores da envergadura de José Cretella Júnior ${ }^{5}$, de Adilson Dallari e Sérgio Ferraz ${ }^{6}$, de Marçal Justen Filho ${ }^{7}$, de Diogo de Figueiredo Moreira Neto ${ }^{8}$ e, sobretudo, de Odete Medauar ${ }^{9}$, que discorreram, cada qual a seu modo, sobre a processualidade do Direito Administrativo.

Essa doutrina jurídica ancora-se na compreensão segundo a qual o processo administrativo é o modo natural de atuação da Administração Pública ${ }^{10}$. Na perspectiva teórica por ela adotada, a atividade administrativa (como a atividade jurisdicional) tem caráter processual ${ }^{11}$.

Essa construção teórica busca inspiração no magistério de Elio Fazzalari, processualista italiano que qualifica o processo como procedimento em contraditório ${ }^{12}$.

A propósito, Odete Medauar leciona que Fazzalari ${ }^{13}$ descreve o processo como estrutura em que se desenvolvem numerosas atividades de direito público, entre elas as atividades desempenhadas pela Administração Pública (atividades administrativas), insertas, no plano da Ciência, no campo de interesses do Direito Administrativo ${ }^{14}$. Por isso, para Medauar ${ }^{15}$, o Direito Administrativo não se limita a disciplinar os atos finais que resultam do exercício da atividade administrativa (decisões/atos administrativos), porque também disciplina a realização de uma série de atividades preparatórias, organizadas em sequência (procedimento), e que servem de estrutura (ou instrumento ${ }^{16}$ ) para a construção das interpretações jurídicas ${ }^{17}$ que possibilitam a

deveria ser azul, e não verde), ou que as pesquisas desenvolvidas no campo da Medicina poderiam apontar como conclusão científica válida a afirmação de que há um equívoco na formação do corpo humano (de modo a propor, ainda exemplificativamente, que o homem deveria ter dois corações).

5 CRETELLA JÚNIOR, José. Prática do processo administrativo. 6. ed. São Paulo: Revista dos Tribunais, 2008.

${ }^{6}$ DALLARI, Adilson; FERRAZ, Sérgio. Processo administrativo. São Paulo: Malheiros, 2001.

7 JUSTEN FILHO, Marçal. Curso de direito administrativo. 12. ed. São Paulo: Revista dos Tribunais, 2016.

8 MOREIRA NETO, Diogo de Figueiredo. Curso de direito administrativo. 16. ed. Rio de Janeiro: Forense, 2014.

9 MEDAUAR, Odete. A processualidade no direito administrativo. 2. ed. São Paulo: Revista dos Tribunais, 2008.

10 Afinal, na lição de Cintra, Grinover e Dinamarco, o processo é instrumento para o legítimo exercício do poder e, por isso, está presente em todas as atividades estatais CINTRA, Antonio Carlos de Araújo; GRINOVER, Ada Pellegrini; DINAMARCO, Cândido Rangel. Teoria geral do processo. 26. ed. São Paulo: Malheiros, 2010. p. 302.

11 MEDAUAR, Odete. A processualidade no direito administrativo. 2. ed. São Paulo: Revista dos Tribunais, 2008. p. 88.

12 FAZZALARI, Elio. Instituições de direito processual civil. 8. ed. Campinas: Bookseller, 2006.

13 FAZZALARI, Elio. Istituzioni di diritto processuale. Padova: Cedam, 1975.

14 MEDAUAR, Odete. O direito administrativo em evolução. 3. ed. Brasília: Gazeta Jurídica, 2017. p. 286.

15 MEDAUAR, Odete. O direito administrativo em evolução. 3. ed. Brasília: Gazeta Jurídica, 2017. p. 286.

16 DINAMARCO, Cândido Rangel. A instrumentalidade do processo. 5. ed. São Paulo: Malheiros, 1996.

17 Administrar, no âmbito estatal, significa aplicar o Direito ÁVILA, Humberto. Repensando o princípio da supremacia do interesse público sobre o particular. In: SARMENTO, Daniel (org.). Interesses públicos versus interesses privados: desconstruindo o princípio da supremacia do interesse público. Rio de Janeiro: Lumen Juris, 2005. p. 173; MARTINS, Ricardo Marcondes. Arbitragem e administração pública: contribuição para o sepultamento do tema. Interesse Público, v. 12, n. 64, p. 85-104, nov./dez. 2010. p. 200. Todavia, o Direito de nosso tempo é flexível; seja porque os textos normativos que o compõem comportam conceitos jurídicos indeterminados, a suscitar, inclusive, a distinção teórica entre regras e princípios; seja porque admite a interferência da jurisdição constitucional, que autoriza o afastamento da aplicação de leis consideradas inconstitucionais, e também da aplicação de leis constitucionais cuja incidência casuística viole a Constituição (duplo juízo de constitucionalidade), que tem incidência muito acentuada no regime brasileiro, que admite, ao lado do controle direto (ou concentrado) da constitucionalidade das leis, também o controle indireto (ou difuso), exercido porque todo e qualquer integrante do Poder Judiciário (processos judiciais) e (num plano mais geral) pelos demais 
sua realização (desses atos finais) e que em geral se encerram (essas atividades preparatórias que compõem o procedimento) com o seu surgimento (desses atos finais) na esfera administrativa.

Porém, a doutrina da processualidade do Direito Administrativo não se restringe a relacionar o Direito Administrativo ao procedimento que antecede à formação dos atos administrativos. Em sintonia com o pensamento de Fazzalari, seus adeptos diferenciam o processo administrativo (compreendido como procedimento em contraditório) do procedimento que o estrutura (compreendido como simples encadeamento de atos). Diversamente do que acontece quando essas atividades preparatórias são tomadas como simples elos de um procedimento, no processo administrativo os sujeitos processuais (Administração, administrados, etc.) têm a oportunidade de participar (contraditório formal ${ }^{18}$ ) e influenciar ${ }^{19}\left(\right.$ contraditório material $\left.^{20}\right)$ a produção dos atos finais praticados pela Administração. Quando assume esses contornos, a produção dos atos administrativos ultrapassa o caráter introspectivo que caracteriza a atividade estatal dissociada da incidência

intérpretes no contexto de sua atuação no âmbito do processo (quando formulam pretensões, quando resistem a pretensões formuladas por seus adversários, quando interpõem recursos, etc.) ou fora dele (quando formam suas respectivas opiniões sobre como o Direito deve ser aplicado), inclusive daqueles (intérpretes) que atuam na esfera administrativa. O que com isso queremos dizer é que, se é verdade que a atividade administrativa guarda estrita vinculação com o Direito, também é certo que o seu exercício também pressupõe, dado o caráter flexível assumido pelo Direito, a interpretação dos seus enunciados prescritivos. MADUREIRA, Claudio. Direito, processo e justiça: o processo como mediador adequado entre o direito e a justiça. Salvador: JusPodivm, 2014. p. 118-122; MADUREIRA, Claudio. Advocacia pública. 2. ed. Belo Horizonte: Fórum, 2016. p. 301-303.

18 DIDIER JÚNIOR, Fredie. Curso de direito processual civil. 17. ed. Salvador: JusPodivm, 2015. v. 1. p. 78-79.

19 Como expusemos em nota anterior, administrar, no âmbito estatal, significa aplicar o Direito. Ao ensejo, recobramos a lição de Humberto Ávila, para quem "a Administração não possui autonomia da vontade", devendo, portanto, "executar a finalidade instituída pelas normas jurídicas constantes na lei dando-lhes ótima aplicação concreta”. Em suas próprias palavras, "a administração não exerce atividade desvinculada, mas apenas exerce, nos fundamentos e limites instituídos pelo Direito, uma função". ÁVILA, Humberto. Repensando o princípio da supremacia do interesse público sobre o particular. In: SARMENTO, Daniel (org.). Interesses públicos versus interesses privados: desconstruindo o princípio da supremacia do interesse público. Rio de Janeiro: Lumen Juris, 2005. p. 173. Nesse mesmo sentido se posiciona, em doutrina, Ricardo Marcondes Martins, quando acentua que o regime privado, porque "baseado na liberdade individual e na autonomia da vontade, na assegurada possibilidade de busca de interesses egoísticos", incompatibiliza-se "com a natureza do Estado, que, por definição, é um ente instrumental", isto é, "existe para o cumprimento de uma função, vale dizer, para a busca do bem comum, para a concretização do interesse público" MARTINS, Ricardo Marcondes. Arbitragem e administração pública: contribuição para o sepultamento do tema. Interesse Público, v. 12, n. 64, p. 85-104, nov./dez. 2010. p. 200. Isso atrai para a atividade administrativa a incidência do dever de motivação adequada das decisões jurídicas, de que tratam os incisos IX e X do artigo 93 da Constituição da República, que impõem aos julgadores que demonstrem, por meio de motivação adequada, a conformidade das suas decisões com os textos normativos aplicados (vinculando-se, portanto, à ideia de legalidade), e possibilitam, ainda, que se confira a necessária transparência (ou publicidade) às razões de decidir (sem a qual não poderiam ser exercidos os direitos fundamentais dos jurisdicionados ao contraditório e à ampla defesa). Muito embora esses dispositivos não se apliquem diretamente à Administração Pública, a circunstância de os atos que ela pratica resultarem de tomadas de posição em sua gênese jurídicas, faz com que, na prática, também se possa impor às autoridades administrativas o dever de motivação adequada das suas decisões. Em primeiro lugar porque a motivação adequada é pressuposto necessário a que se estabeleça o necessário controle da juridicidade sobre os atos administrativos imposto à Administração e aos seus agentes pelo princípio administrativo da legalidade, positivado no caput do artigo 37 da Constituição Brasileira. Em segundo lugar porque a sua veiculação está intrinsicamente ligada à observância do princípio administrativo da publicidade, também extraído do mesmo dispositivo da Lei Maior, porque é a motivação que possibilita, nos casos concretos, a publicização dos motivos que levaram à prática de determinado ato administrativo. Em terceiro lugar porque se ela não for implementada nos processos administrativos, não serão atendidos, na casuística, os direitos ao contraditório e à ampla defesa, assegurados aos litigantes pelo inciso LV do artigo $5^{\circ}$ da Carta de 1988 tanto nos processos judiciais quanto nos administrativos. Porém, é recomendável que, na ausência de critério normativo específico aplicável aos processos administrativos, os agentes estatais empreguem, para atingir esse objetivo, o modelo decisório positivado no parágrafo $1^{\circ}$ do artigo 489 do Código de Processo Civil de 2015, seja porque os parâmetros contidos nesse dispositivo parecem ser mais adequados (tendo em vista a incidência dos princípios da isonomia, da impessoalidade e da segurança jurídica) para orientar as tomadas de posição na esfera administrativa do que as opiniões pessoais e individuais de cada agente estatal chamado a motivar os atos que pratica, seja porque a própria lei processual civil projeta, em seu artigo 15, a aplicação das suas disposições aos processos administrativos. Dele resulta que não se pode considerar adequadamente fundamentada (entre outras) a decisão que não enfrenta as razões deduzidas pelas partes no processo (CPC-2015, art. 489, p. $1^{\circ}$, IV), e que, portanto, entre nós a garantia do contraditório ultrapassa o direito de participar do processo (contraditório formal), para também alcançar o direito a influir nas decisões nele proferidas (contraditório material). DI PIETRO, Maria Sylvia Zanella. Direito administrativo. 32. ed. Rio de Janeiro: Forense, 2019. p. 109. Sobre o assunto, ler também: MADUREIRA, Claudio. Licitações, contratos e controle administrativo: descrição sistemática da Lei n. ${ }^{\circ} 14.133 / 2021$ na perspectiva do Modelo Brasileiro de Processo. Belo Horizonte: Fórum, 2021. p. 500-502; MADUREIRA, Claudio. Royalties de petróleo e Federação. Belo Horizonte: Fórum, 2012. p. 194-195.

${ }^{20}$ DIDIER JÚNIOR, Fredie. Curso de direito processual civil. 17. ed. Salvador: JusPodivm, 2015. v. 1. p. 79. 
do contraditório, que de igual modo é exercitada com a aspiração de conferir validade dos atos praticados pela Administração, mas num contexto em que a adequação desses atos ao Direito e aos fatos subjacentes à sua aplicação nos casos concretos é aferida sob a ótica exclusiva dos agentes estatais responsáveis pelo seu surgimento na esfera administrativa ${ }^{21}$. Por isso a atividade administrativa, quando estruturada pela doutrina da processualidade do Direito Administrativo, confere melhores resultados ao exercício da função administrativa, proporcionados pela abertura democrática e pluralista dos atos decisórios praticados nesse contexto aos vários pontos de vista, argumentos e interpretações dos fatos ${ }^{22}$.

\section{Processo e procedimento administrativo na Lei $n .^{\circ} 14.133 / 2021$}

Esse modelo teórico parece ter sido adotado pela Lei n. ${ }^{\circ}$ 14.133/2021.

Em primeiro lugar porque o seu Título II, que trata "Das Licitações", inicia-se por capítulo dedicado (nas palavras do legislador) ao "Processo de Licitação"23. Muito embora a Lei n. ${ }^{\circ}$ 8.666/1993 tenha utilizado essa mesma expressão no parágrafo $5^{\circ}$ do seu artigo $3^{\circ}$, no inciso XII do seu artigo 24 e no parágrafo $1^{\circ}$ do seu artigo 40, como regra as licitacões vinham qualificadas em seu texto como simples procedimento, conforme se verifica, a título de exemplo, do disposto no parágrafo único do seu artigo $4^{\circ}$, no parágrafo $3^{\circ}$ do seu artigo 13 , no inciso III do seu artigo 19, no seu artigo 38, no seu artigo 49, nos parágrafos $1^{\circ}$ e $2^{\circ}$ do mesmo artigo 49, no seu artigo 50, no seu artigo 90, no seu artigo 93, no seu artigo 94 e no seu artigo 122, essa lógica se inverteu na novatio legis. Nela, apenas três dispositivos referem-se às licitações como procedimento. O primeiro deles é o inciso LX do artigo $6^{\circ}$, que define os agentes de contratação como as pessoas designadas pela autoridade competente para tomar decisões, acompanhar o trâmite da licitação, dar impulso ao procedimento licitatório e executar quaisquer outras atividades necessárias ao bom andamento do certame até a homologação. O segundo é o seu artigo $8^{\circ}$, que prescreve que as licitações serão conduzidas por agentes de contratação, e que por isso reitera a definição feita pelo inciso LX do artigo $6^{\circ}$, dispondo tratarem-se das pessoas designadas pela autoridade competente para tomar decisões, acompanhar o trâmite da licitação, dar impulso ao procedimento licitatório e executar quaisquer outras atividades necessárias ao bom andamento do certame até a homologação. E o terceiro e último deles é o artigo 147, que enuncia que, quando for constatada alguma irregularidade no procedimento licitatório ou na execução contratual, caso não seja possível o saneamento, a decisão sobre a suspensão da execução ou anulação do contrato pode ser evitada quando não atender ao interesse público. Porém, todos esses preceitos se referem, claramente, ao procedimento do processo licitatório, ou seja, ao encadeamento de atos praticados no curso daquele processo.

Em segundo lugar porque, como as licitações, também as contratações públicas são formalizadas, executadas e extintas, no novo regime normativo, no corpo de processos administrativos. A uma porque a Lei n. ${ }^{\circ}$ 14.133/2021 assim o previu em diversos de seus dispositivos, de que são exemplo as previsões contidas (i) no caput de seu artigo 91, que estabelece que os contratos e seus aditamentos terão forma escrita e serão juntados ao processo que tiver dado origem à contratação, divulgados e mantidos à disposição do público em sítio eletrônico oficial, (ii) no parágrafo $4^{\circ}$ do mesmo dispositivo, que prescreve que a Administração, antes de formalizar ou prorrogar o prazo de vigência do contrato, deverá verificar a regularidade fiscal do contratado,

\footnotetext{
21 Aliás, é por isso que, na prática, a processualidade do Direito Administrativo culmina por ampliar as chances de que as decisões administrativas subjacentes à prática desses atos finais da Administração venham a ser aceitas pelos interessados na sua prolação. A propósito, MADUREIRA, Claudio. Fundamentos do novo processo civil brasileiro: o processo civil do formalismo-valorativo. Belo Horizonte: Fórum, 2017. p. 109-124.

22 MEDAUAR, Odete. A processualidade no direito administrativo. 2. ed. São Paulo: Revista dos Tribunais, 2008. p. 88-89.

23 Sobre a argumentação que se segue. MADUREIRA, Claudio. Licitações, contratos e controle administrativo: descrição sistemática da Lei n. ${ }^{\circ}$ 14.133/2021 na perspectiva do Modelo Brasileiro de Processo. Belo Horizonte: Fórum, 2021. p. 139-141.
} 
consultar o $\mathrm{CEIS}^{24}$ e o $\mathrm{CNEP}^{25}$, emitir as certidões negativas de inidoneidade, de impedimento e de débitos trabalhistas e juntá-las ao respectivo processo, (iii) no parágrafo $1^{\circ}$ do artigo 122 , que determina ao contratado que apresente à Administração documentação que comprove a capacidade técnica do subcontratado, para avaliação e juntada aos autos do processo correspondente, (iv) no caput do artigo 137, que preceitua que os motivos para extinção do contrato (especificados em seus incisos) deverão ser formalmente apresentados nos autos do processo, e (v) no parágrafo $1^{\circ}$ do artigo 138, que condiciona a extinção do contrato (seja por ato unilateral da Administração, seja por consenso entre as partes) à autorização escrita e fundamentada da autoridade competente e reduzidas a termo no respectivo processo. A duas porque o legislador, quando se reportou, no texto da novatio legis, ao princípio do contraditório, não referiu apenas à sua incidência no processo licitatório; conforme podemos verificar (i) do texto do seu artigo 21, que disciplina a realização de audiência pública que possibilite a manifestação de todos os interessados, (ii) do parágrafo $3^{\circ}$ do seu artigo 71 , que condiciona a prolação de decisão sobre anulação ou revogação da licitação a prévia manifestação dos interessados, estendendo-o, ainda, aos processos administrativos voltados à formalização de contratações públicas, (iii) do que prescreve o seu artigo 137, que condiciona a extinção dos contratos administrativos à observância do contraditório e da ampla defesa, e (iv) dos seus artigos 157, 158 e 160, que aplicam essa garantia em matéria de atribuição de sanções a licitantes/contratados.

O que com isso queremos dizer é que o legislador promoveu relevante modificação no tratamento normativo conferido às licitações e contratações públicas. Com efeito, se no regime da Lei n. ${ }^{\circ}$ 8.666/1993 elas eram encaradas como simples procedimentos, na lei nova elas passaram a assumir a conotação de autênticos processos administrativos.

\section{Processo, procedimento e flexibilização do formalismo processual nos processos de licitação e contratação pública}

A distinção entre processo e procedimento insere-se entre os objetos de análise do direito processual. Quanto ao particular, reportamo-nos ao magistério de Hermes Zaneti Júnior, para quem o processo "é o caminho para a realização com justiça do direito material resistido, controverso", visto que é por meio dele que "fazemos a escrita, pelo poder estatal ${ }^{26}$ da nova ordem jurídica, pacificando o conflito e entregando a cada um o que é seu" ${ }^{27}$. Conforme Zaneti, o processo é compreendido, nessa perspectiva, como o procedimento em contraditório, portanto também em sintonia com o magistério de Elio Fazzalari ${ }^{28}$; num contexto em que o contraditório "o qualifica não mais como gênero, mas sim como espécie de procedimento" 29 ; o que valoriza a participação dos interessados na formação da decisão e possibilita a efetiva realização do direito fundamental positivado no inciso LV do artigo $5^{\circ}$ da Constituição da República, que enuncia, em literalidade, que aos litigantes, em processo judicial ou administrativo, e aos acusados em geral são assegurados o contraditório e a ampla defesa, com os meios e recursos a ela inerentes ${ }^{30}$.

\footnotetext{
${ }^{24}$ Cadastro Nacional de Empresas Inidôneas e Suspensas.

25 Cadastro Nacional de Empresas Punidas.

${ }^{26}$ Zaneti se reporta, nessa passagem, às decisões proferidas pelo Poder Judiciário, mas a sua fala também se aplica, por similitude de premissas, às decisões administrativas.

27 ZANETI JÚNIOR, Hermes. Processo constitucional: o modelo constitucional do processo civil brasileiro. Rio de Janeiro: Lumen Juris, 2007. p. 204.

28 FAZZALARI, Elio. Instituições de direito processual civil. 8. ed. Campinas: Bookseller, 2006.

29 ZANETI JÚNIOR, Hermes. Processo constitucional: o modelo constitucional do processo civil brasileiro. Rio de Janeiro: Lumen Juris, 2007. p. 190.

${ }^{30}$ Talvez por esse motivo o legislador tenha referido ao contraditório, no texto da Lei n. ${ }^{\text {0 }}$ 14.133/2021, em diversos de seus dispositivos; conforme se verifica, a título de exemplo, do seu artigo 21 (que disciplina a realização de audiência pública que possibilite a manifestação de todos os interessados), do parágrafo $3^{\circ}$ do seu artigo 71 (que condiciona a prolação de decisão sobre anulação ou revogação da licitação à prévia manifestação dos interessados), do seu artigo 137 (que condiciona a extinção dos contratos administrativos à observância do contraditório e da ampla defesa) e dos seus artigos 157, 158 e 160 (que aplicam essas garantias em matéria
} 


\subsection{A doutrina do formalismo-valorativo como pano de fundo para a flexibilização procedimental almejada}

A designação do processo como procedimento em contraditório ${ }^{31}$ guarda estrita relação com a doutrina do formalismo-valorativo, concebida no âmbito da escola processual gaúcha sob a liderança de Carlos Alberto Alvaro de Oliveira ${ }^{32}$, adiante difundida, na mesma escola, por Daniel Mitidiero ${ }^{33}$, e posteriormente assimilada, por influência de Zaneti, pela escola processual capixaba ${ }^{34}$. Seu escopo, nas palavras de Alvaro de Oliveira ${ }^{35}$, é o de "analisar a antinomia existente entre formalismo e justiça, buscando dar solução a esse aflitivo problema que assola o direito processual" ${ }^{\prime 3}$. Para tanto, o formalismo-valorativo (i) qualifica o processo como um direito do cidadão, o que faz incidir sobre as normas que o disciplinam o regime jurídico dos direitos fundamentais ${ }^{37}$, (ii) defende a existência de um direito fundamental do jurisdicionado ao processo justo ${ }^{38}$ e (iii) sustenta que o Direito é reconstruído (ou recriado) pelos intérpretes no contexto da aplicação dos textos normativos aos casos concretos (justa aplicaşão do Direito), mormente no ambiente processual, sob a mediação do formalismo que lhe é característico ${ }^{39}$. Para seus adeptos, a realização da justiça no processo, porque

de atribuição de sanções a licitantes/contratados).

$31 \mathrm{Na}$ linha do que defende (em estudos relativos ao direito processual) o professor italiano Elio Fazzalari. FAZZALARI, Elio. Instituições de direito processual civil. 8. ed. Campinas: Bookseller, 2006. (No âmbito administrativo, mas a partir do seu magistério) a doutrina da processualidade do Direito Administrativo (a propósito, cf., por todos. MEDAUAR, Odete. A processualidade no direito administrativo. 2. ed. São Paulo: Revista dos Tribunais, 2008.

32 Quanto ao particular, por todos: OLIVEIRA, Carlos Alberto Alvaro de. Do formalismo no processo civil. 3. ed. São Paulo: Saraiva, 2009.

33 A ensejo, a título de exemplo: MITIDIERO, Daniel. Colaboração no processo civil: pressupostos sociais, lógicos e éticos. 3. ed. São Paulo: Revista dos Tribunais, 2015.

34 Entre os trabalhos produzidos nesse âmbito sobre o formalismo-valorativo, cf., ainda exemplificativamente: MADUREIRA, Claudio. Direito, processo e justiça: o processo como mediador adequado entre o direito e a justiça. Salvador: JusPodivm, 2014; MADUREIRA, Claudio. Fundamentos do novo processo civil brasileiro: o processo civil do formalismo-valorativo. Belo Horizonte: Fórum, 2017; MADUREIRA, Claudio; ZANETI JÚNIOR, Hermes. Formalismo-valorativo e o novo processo civil. Revista de Processo, São Paulo, v. 42, n. 272, out. 2017; MADUREIRA, Claudio; ZANETI JÚNIOR, Hermes. Processos estruturais e formalismovalorativo. In: SICA, Heitor et al. (org.). Temas de direito processual contemporaneo: III Congresso Brasil-Argentina de Direito Processual. Serra: Milfontes, 2019. v. 2. Nas palavras do autor: “[...] há, na obra de Claudio Madureira, uma curiosidade a ser ressaltada desde já, em especial quando anuncia que no Mestrado em Direito da Universidade Federal do Espírito Santo, Hermes Zaneti Júnior tem levado os ensinamentos de Carlos Alberto Alvaro de Oliveira, tendo, inclusive, sido influenciado pelo processualista gaúcho (hoje praticamente mais capixaba em suas atividades acadêmicas e profissionais) durante as aulas para assumir, na defesa de sua tese, referida fase cultural como sendo a que realmente explica o processo civil contemporâneo. Mas se existe uma vinculação entre o formalismo-valorativo e Hermes Zaneti, o que faria da Universidade Federal do Espírito Santo o berço de uma Escola de Processo? A resposta parece estar na linha de pesquisa que o Programa de Pós-Graduação em Direito oferece aos seus mestrandos sobre Sistema de Justiça, Constitucionalidade e Tutela de Direito Individuais e Coletivos, que propõe uma leitura do fenômeno processual atento às necessidades, por meio da judicialização dos conflitos sociais e coletivos, promovendo a justiça social, ou seja, o diferencial é o estudo da coletivização dos direitos e sua tutela". JOBIM, Marco Felix. Cultura, escolas e fases metodologicas do processo. Porto Alegre: Livraria do Advogado, 2018. p. 122-123.

35 A propósito, Zaneti relata que a expressão formalismo-valorativo foi cunhada por Alvaro de Oliveira em aula do Programa de Pós-Graduação em Direito da Universidade Federal do Rio Grande do Sul no ano de 2004 ZANETI JÚNIOR, Hermes. Processo constitucional: o modelo constitucional do processo civil brasileiro. Rio de Janeiro: Lumen Juris, 2007. p. 44.

36 OLIVEIRA, Carlos Alberto Alvaro. O formalismo-valorativo no confronto com o formalismo excessivo. Gênesis: Revista de Direito Processual Civil, v. 11, n. 39, p. 15-36, jan./jun., 2006. p. 13.

${ }^{37}$ MADUREIRA, Claudio. Direito, processo e justiça: o processo como mediador adequado entre o direito e a justiça. Salvador: JusPodivm, 2014. p. 77-79.

38 ZANETI JÚNIOR, Hermes. Processo constitucional: o modelo constitucional do processo civil brasileiro. Rio de Janeiro: Lumen Juris, 2007. p. 44.

${ }_{39}$ Os intérpretes, quando aplicam o Direito, partem dos textos normativos, procurando adaptá-los às especificidades do ambiente fático que emoldura a contenda e, por vezes, temperando-os com os valores juridicizados pelo legislador no corpo dos princípios jurídicos. Sobre o relacionamento entre princípios e valores, Humberto Ávila leciona que "os valores constituem o aspecto axiológico das normas, na medida em que indicam que algo é bom e, por isso, digno de ser buscado ou preservado", ao passo que os princípios "constituem o aspecto deontológico dos valores, pois, além de demonstrarem que algo vale a pena ser buscado, determinam que esse estado de coisas deve ser promovido". ÁVILA, Humberto. Teoria dos princípios: da definição à aplicação dos princípios jurídicos. $4^{\text {a }}$ ed. São Paulo: Malheiros, 2005. p. 95. Opera-se, pois, mais propriamente, um processo de reconstrução do direito positivo, sob a mediação dos fatos e dos direitos fundamentais (usualmente reproduzidos sob a forma de princípios jurídicos), com vistas à efetiva realização dos direitos e da justiça. A tecnologia empregada pelos formalistas-valorativos é ilustrada pela Teoria Circular dos 
comporta a reconstrução normativa a cargo dos intérpretes (justa aplicação do Direito), também pressupõe a efetiva consideração (contraditório formal) e (mais do que isso) o necessário enfrentamento (contraditório material) das razões deduzidas no curso do procedimento pelos interessados na decisão que nele será proferida (processo justo). Conforme Zaneti, “é justamente no contraditório, ampliado pela Carta do Estado Democrático Brasileiro, que se irá apoiar a noção de processo democrático, o processo como procedimento em contraditório, que tem na sua matriz substancial a 'máxima da cooperação' (Kooperationsmaxima)", num contexto em que ele (contraditório) surge "renovado, não mais unicamente como garantia do direito de resposta, mas sim como direito de influência e dever de debate" ${ }^{40}$.

As circunstâncias de o processo se apresentar, dentro dessa perspectiva teórica, como direito fundamental dos interessados na formação da decisão - a quem interessa a aplicação do Direito com justiça (justa aplicação do Direito, assim compreendida aquela instrumentalizada em um processo justo ${ }^{41}$ ), e de essa decisão amparar-se em exercício de reconstrução (pelos intérpretes) do Direito positivado nos textos normativos (aplicação de um Direito justo ${ }^{42}$ ) - demanda a configuração de um processo dialético, ou dialógico, que possibilite a legitimação democrática da decisão nos casos concretos (legitimação pelo procedimento). É que, conforme Alvaro de Oliveira, o formalismo (ou forma em sentido amplo) não deve ser confundido com a forma do ato processual individualmente considerado, porque "diz respeito à totalidade formal do processo", na medida em que compreende

não só a forma, ou as formalidades, mas especialmente a delimitação dos poderes, faculdades e deveres dos sujeitos processuais, a coordenação de sua atividade, a ordenação do procedimento e a organização do processo, com vistas a que sejam atingidas suas finalidades primordiais ${ }^{43}$.

O formalismo visa, então, assegurar a consecução das finalidades do processo, com destaque para a proteção do interessado contra a prolação de decisões jurídicas arbitrárias (e, por isso mesmo, potencialmente injustas) que podem resultar da inclinação teórica quanto a competir aos juízes (no processo judicial) e a Administração (nos processos administrativos) solucionar os litígios sob a ótica introspectiva da sua percepção pessoal sobre os casos julgados, portanto num contexto em que aquele que decide não estaria obrigado a considerar e efetivamente enfrentar as razões apresentadas pelos interessados na prolação da decisão ${ }^{44}$. To-

Planos (inicialmente designada por Zaneti como "Teoria da Relação Circular"; a propósito. ZANETI JÚNIOR, Hermes. Direito material e direito processual: relações e perspectivas. Revista Processo e Constituição - Cadernos Galeno Lacerda de Estudos de Direito ProcessualConstitucional, Porto Alegre, v. 1, p. 245-278, 2004. p. 248), segundo a qual "o processo deve partir do direito material, da realidade substancial, e ao direito material deve voltar". MITIDIERO, Daniel. Elementos para uma teoria contemporânea do processo civil brasileiro. Porto Alegre: Livraria do Advogado, 2005. p. 70. O que Zaneti acentua, nesse contexto, é que "o processo devolve (sempre) algo diverso do direito material afirmado pelo autor, na inicial, algo que por sua vez é diverso mesmo da norma expressa do direito material positivado", de maneira "que entre o processo e o direito material ocorre uma relação circular", segundo a qual "o processo serve ao direito material, mas para que lhe sirva é necessário que seja servido por ele". ZANETI JÚNIOR, Hermes. Processo constitucional: o modelo constitucional do processo civil brasileiro. Rio de Janeiro: Lumen Juris, 2007. p. 204-205. Disso resulta, "que o direito processual é essencial ao direito material, assim como esse é igualmente fundamental àquele". MITIDIERO, Daniel. Elementos para uma teoria contemporânea do processo civil brasileiro. Porto Alegre: Livraria do Advogado, 2005. p. 71. Afinal, "sem o direito material, o processo civil simplesmente não teria função alguma", enquanto que "sem o direito processual, o direito material não conseguiria superar eventuais crises na sua realização". MITIDIERO, Daniel. Elementos para uma teoria contemporânea do processo civil brasileiro. Porto Alegre: Livraria do Advogado, 2005. p. 71; MADUREIRA, Claudio. Recasens Siches e a aplicação do direito a partir da interação entre norma, fato e valor. Derecho y Cambio Social, n. 40, abr. 2015.

40 ZANETI JÚNIOR, Hermes. Processo constitucional: o modelo constitucional do processo civil brasileiro. Rio de Janeiro: Lumen Juris, 2007. p. 191-192.

${ }_{41}$ DINAMARCO, Cândido Rangel. A instrumentalidade do processo. 5. ed. São Paulo: Malheiros, 1996; BEDAQUE, José Roberto dos Santos. Direito e processo. 4. ed. São Paulo: Malheiros, 2006.

42 Que a diferencia do instrumentalismo. MADUREIRA, Claudio. Fundamentos do novo processo civil brasileiro: o processo civil do formalismo-valorativo. Belo Horizonte: Fórum, 2017. p. 50-54.

43 OLIVEIRA, Carlos Alberto Alvaro. O formalismo-valorativo no confronto com o formalismo excessivo. Gênesis: Revista de Direito Processual Civil, v. 11, n. 39, p. 15-36, jan./jun., 2006. p. 14.

44 A propósito, Daniel Mitidiero acentua que contraditório "não se cinge mais a garantir tão somente a bilateralidade da instância, antes conferindo direito, tanto ao demandante como ao demandado, de envidar argumentos para influenciar na conformação da decisão judicial”. MITIDIERO, Daniel. Processo civil e estado constitucional. Porto Alegre: Livraria do Advogado, 2007. p. 37. Assim, para esse professor gaúcho, o contraditório é mais do que uma simples norma de igualdade formal, pois assume "papel central 
davia, o processo não deve ser encarado, nessa perspectiva, como ato formal e inflexível (forma), mas como formalidade indispensável a regular e orientar o procedimento. É que ele (processo) não é fim em si mesmo, exatamente porque, em seu curso, a "forma serve como garantia, e não amarra da justiça"

\subsection{A adstrição do Modelo Brasileiro de Processo à doutrina do formalismo-valorativo e a viabilidade da extensão da sua aplicação aos processos que encartam licitações e contratações públicas}

Conforme já se observou em doutrina ${ }^{46}$, esse modelo de processo parece ter sido assimilado pelo Código de Processo Civil de 2015, que estabelece, entre outras coisas, que se considera desprovido de regular fundamentação o ato decisório (seja ele uma decisão, uma sentença ou um acórdão) (i) que deixa de seguir enunciado de súmula, jurisprudência ou precedente por elas invocado e que seja aplicável ao caso (ausência de distinção) e não tenha sido superado (art. 489, p. $1^{\circ}, \mathrm{VI}^{47}$ ), aderindo, portanto, à proposição teórica quanto a ser viável a reconstrução dos textos legais pelos intérpretes/operadores do Direito, com o propósito de promover a sua justa aplicação nos casos concretos, e também aquele (ii) que não enfrenta todos as raz̃ões deduzidas pelas partes no processo (art. 489, p. $1^{\circ}, \mathrm{IV}^{48}$ ), condicionando a validade do direito aplicado não apenas à participação dos interessados na decisão (contraditório formal), mas também à sua efetiva capacidade de influir no resultado do processo (contraditório material).

Por esse motivo, e considerando que a atividade administrativa é (ou pelo menos deveria ser) exercitada no curso de processos administrativos (tendo em vista a construção teórica que sobressai da doutrina da processualização do Direito Administrativo), inclusive aquela desenvolvida nas licitações e contratações públicas (dada a adesão da Lei n. ${ }^{\circ}$ 14.133/2021 a esse modelo teórico), e considerando que o artigo 15 da lei

na experiência do processo, cujo resultado não pode ser outro que não um 'ato de três pessoas', como um autêntico ambiente democrático e cooperativo” MITIDIERO, Daniel. Processo civil e estado constitucional. Porto Alegre: Livraria do Advogado, 2007. p. 37-38. Conforme Mitidiero essa acepção renovada do contraditório é resultado da consolidação da "dimensão ativa do caráter fortemente problemático do direito contemporâneo, constatação hoje igualmente corrente, e da complexidade do ordenamento jurídico atual”. MITIDIERO, Daniel. Processo civil e estado constitucional. Porto Alegre: Livraria do Advogado, 2007. p. 37. E induz a compreensão de que a tarefa dos juízes, quanto ao particular, não se exaure na iniciativa de oportunizar às partes uma manifestação no processo, abarcando, também (e principalmente), a imposição a que, na motivação de suas decisões, efetivamente considerem e enfrentem as razões apresentadas. Seguindo no raciocínio, tem-se que a extensão e a profundidade da motivação construída pelo magistrado para justificar a sua decisão é também decorrência do princípio do contraditório.

45 ZANETI JÚNIOR, Hermes. Processo constitucional: o modelo constitucional do processo civil brasileiro. Rio de Janeiro: Lumen Juris, 2007. p. 49. Ele funciona, precisamente em razão do formalismo que lhe é característico, como mecanismo de controle da atividade decisória, já que, em seu corpo, instaura-se uma relação dialética entre as partes reciprocamente e entre elas e aquele que decide, no curso da qual o julgador e os contendores conjugam seus esforços no sentido da justa aplicação do Direito, equilíbrio que, segundo Zaneti, somente é possível “em um quadro institucional que constrange à 'disponibilidade para a cooperação', marcada por 'regras do jogo' previamente delimitadas e objetivando resultados não-conceituais, à medida que podem ser aceitos pelos participantes por razões diferentes". ZANETI JÚNIOR, Hermes. Processo constitucional: o modelo constitucional do processo civil brasileiro. Rio de Janeiro: Lumen Juris, 2007. p. 168. Daí a afirmação, pelos adeptos do formalismo-valorativo, em referência ao processo judicial (objeto de suas reflexões no campo do Direito Processual), de que um modelo ideal de processo seria aquele em que o julgador é paritário no diálogo (assumindo, assim, uma postura democrática frente ao processo, o que pressupõe a consideração e o efetivo enfrentamento de das razões apresentadas pelas partes em suas manifestações processuais) e assimétrico apenas na decisão (o que significa dizer que ele, após considerar e enfrentar as razões apresentadas por uma e outra parte, deverá apresentar uma solução para o litígio). MITIDIERO, Daniel. Colaboração no processo civil: pressupostos sociais, lógicos e éticos. 3. ed. São Paulo: Revista dos Tribunais, 2015. p. 64-65. Ambiente dialógico que, para além de prevenir o arbítrio estatal no campo da aplicação do Direito, fomenta as condições necessárias a que os interessados reconheçam a justeza da decisão prolatada, o que converte o processo, sob a mediação do formalismo que lhe é característico, em um verdadeiro instrumento da justiça.

46 MADUREIRA, Claudio. Fundamentos do novo processo civil brasileiro: o processo civil do formalismo-valorativo. Belo Horizonte: Fórum, 2017.

47 CPC-2015. "Art. 489 [...]\ $1^{\circ}$ Não se considera fundamentada qualquer decisão judicial, seja ela interlocutória, sentença ou acórdão, que: [...] VI - deixar de seguir enunciado de súmula, jurisprudência ou precedente invocado pela parte, sem demonstrar a existência de distinção no caso em julgamento ou a superação do entendimento".

48 CPC-2015. "Art. 489 [...]\} 1 ^ { \circ } \text { Não se considera fundamentada qualquer decisão judicial, seja ela interlocutória, sentença ou } acórdão, que: [...] IV - não enfrentar todos os argumentos deduzidos no processo capazes de, em tese, infirmar a conclusão adotada pelo julgador". 
processual dispõe, textualmente, sobre a aplicação dos seus preceitos também aos processos administrati$\operatorname{vos}^{49}$, a conclusão que se impõe é que o caráter dialético do modelo de processo por ela instituído (propiciado pela incidência do princípio processual do contraditório), quando conjugado à compreensão de que o Direito de nosso tempo é flexivel (e que por isso comporta reconstrução normativa pelos intérpretes no campo da sua aplicação) e de que a Constituição Brasileira confere ao cidadão direito subjetivo ao processo justo (procedural due process ${ }^{50}$ ) e à justa aplicação do Direito (substantive due process ${ }^{51}$ ), pode ser empregado, nos casos concretos, para flexibilizar o rigor procedimental a que se atribui, no plano dos fatos, a ineficiência das licitações e contratações públicas.

\subsection{Algumas ferramentas jurídicas que sobressaem do Modelo Brasileiro de Processo}

Nesse campo, tem especial importância a incidência do princípio processual da instrumentalidade das formas, que enuncia que "nem todo vício é capaz de preordenar a nulidade do processo" (inclusive dos processos administrativos relativos a licitações e contratações públicas) "ou de qualquer dos seus atos" (praticados, na hipótese analisada, com o propósito de possibilitar a seleção de licitantes e a formalização/execução das contratações públicas ${ }^{52}$. Esse princípio, nas palavras de Enrico Tullio Liebman, subordina a invalidade de um ato processual não à simples inobservância da forma, mecanicamente constatada, mas à relação, apreciada por caso, entre o vício e a finalidade do ato ${ }^{53}$. Disso resulta a observação de José Roberto dos Santos Bedaque no sentido de que, em vista da sua incidência, "toda vez que um ato processual, não obstante praticado em desconformidade com o modelo legal, atingir o seu escopo, a nulidade não deve ser declarada"; precisamente porque, como dispôs adiante o processualista, "o princípio da legalidade das formas e a necessidade de observância às regras do procedimento são garantia do resultado do processo"; pelo que, "se este for alcançado, deixa de ter relevância o não atendimento à forma" ${ }^{\prime 54}$.

A instrumentalidade das formas pode ser empregada (como ferramenta jurídica) para a resolução de problemas relativos a licitações e contratos quando se cogita (por exemplo) da convalidação de atos praticados na esfera administrativa, amplamente admitida pela tradição jurídica em caso de nulidade relativa ${ }^{55}$; pos-

\footnotetext{
${ }^{49}$ CPC-2015. "Art. 15 - Na ausência de normas que regulem processos eleitorais, trabalhistas ou administrativos, as disposições deste Código lhes serão aplicadas supletiva e subsidiariamente".

${ }^{50}$ Relacionada à tutela processual, NERY JÚNIOR, Nelson. Princípios do processo civil na Constituição Federal. 7. ed. São Paulo: Revista dos Tribunais, 2002. p. 37. Portanto à estruturação de um processo justo. MADUREIRA, Claudio. Direito, processo e justiça: o processo como mediador adequado entre o direito e a justiça. Salvador: JusPodivm, 2014. p. 35-56.

51 Relacionado ao direito material ou, mais especificamente, à "tutela daqueles direitos por meio do processo judicial ou administrativo". NERY JÚNIOR, Nelson. Princípios do processo civil na Constituição Federal. 7. ed. São Paulo: Revista dos Tribunais, 2002. p. 37. Portanto à justa aplicação do Direito MADUREIRA, Claudio. Direito, processo e justiça: o processo como mediador adequado entre o direito e a justiça. Salvador: JusPodivm, 2014. p. 57-91.

52 A propósito, confira-se, por todos: BRASIL JÚNIOR, Samuel Meira. Justiça, direito e processo: a argumentação e o direito processual de resultados justos. São Paulo: Atlas, 2007. p. 03-33.

53 LIEBMAN, Enrico Tullio. Manual de direito processual civil. 3. ed. São Paulo: Malheiros, 2005. v. 1. p. 328.

54 BEDAQUE, José Roberto dos Santos. Direito e processo. 4. ed. São Paulo: Malheiros, 2006. p. 113.

55 No ponto, é importante recobrar a distinção teórica entre atos nulos, inexistentes e anuláveis. Os atos nulos são aqueles que nascem com vício insanável, porque não são passíveis de correção pela Administração, e por isso (como regra) não produzem efeitos. JUSTEN FILHO, Marçal. Curso de direito administrativo. 12. ed. São Paulo: Revista dos Tribunais, 2016. p. 461. Os atos inexistentes, por sua vez, são aqueles que possuem um vício gravíssimo na sua formação, e por isso não produzem (jamais) efeitos jurídicos. MELLO, Celso Antônio Bandeira de. Curso de direito administrativo. 30. ed. São Paulo: Malheiros, 2013. p. 480-481. Já atos anuláveis são aqueles que apresentam vícios sanáveis (ou seja, passíveis de correção/convalidação). CARVALHO, Mateus. Manual de direito administrativo. 6. ed. Salvador: JusPodivm, 2019. p. 307. Assim, em princípio, apenas seria viável o retorno para saneamento de atos portadores de vícios sanáveis, portanto de atos anuláveis, associados por Marçal Justen Filho ao conceito de nulidade relativa, que "ocorre quando o defeito afeta interesses disponíveis de sujeitos específicos”. JUSTEN FILHO, Marçal. Curso de direito administrativo. 12. ed. São Paulo: Revista dos Tribunais, 2016. p. 461.
} 
sibilidade teórica que foi estendida pela Lei n. ${ }^{\circ} 14.133 / 2021$ (art. $147^{56}$ e p. único ${ }^{57}$ c/c art. $148^{58}$ ) mesmo a atos contaminados por nulidade absoluta, quando a sua preservação, com consequente afastamento da decretação da nulidade do ato, configurar medida de interesse público ${ }^{59}$. Porém, em uma e outra situação, questão relevante que se coloca é saber quando o ato portador de vício que em tese pode caracterizar nulidade absoluta ou relativa deve ser anulado e quando ele deve ser preservado. Muito embora essa pergunta apenas possa ser efetivamente respondida na casuística, mediante a consideração das especificidades de cada caso concreto, a incidência do princípio da instrumentalidade das formas permite definir, de antemão, que a convalidação cogitada pressupõe que do vício apontado (irregularidade) não resultem prejuízos (para os casos de nulidade relativa) que não possam ser sanados pela indenização cogitada pelo texto da Lei $n^{0} 14.133 / 2021$ (para os casos de nulidade relativa suprível pela invocação do interesse público). Afinal, também decorre desse princípio processual a imposição a que se pronuncie a nulidade de ato processual quando o vício apontado ocasionar prejuízo a uma das partes (pas nullité sans grief) ${ }^{60}$.

Porém, a verificação, em concreto, de que da flexibilização do formalismo processual não resultará prejuízo aos interessados na decisão de igual modo demanda a potencialização dos efeitos da incidência, nas licitações e contratações públicas, do princípio processual do contraditório ${ }^{61}$ e, sobretudo, da sua conjugação ao princípio processual

\footnotetext{
${ }^{56}$ Lei n. $^{\circ}$ 14.133/2021. "Art. 147. Constatada irregularidade no procedimento licitatório ou na execução contratual, caso não seja possível o saneamento, a decisão sobre a suspensão da execução ou sobre a declaração de nulidade do contrato somente será adotada na hipótese em que se revelar medida de interesse público, com avaliação, entre outros, dos seguintes aspectos: [...]".

57 Lei n.o 14.133/2021. "Art. 147 [...] Parágrafo único. Caso a paralisação ou anulação não se revele medida de interesse público, o poder público deverá optar pela continuidade do contrato e pela solução da irregularidade por meio de indenização por perdas e danos, sem prejuízo da apuração de responsabilidade e da aplicação de penalidades cabíveis".

58 Lei n. ${ }^{0}$ 14.133/2021. "Art. 148. A declaração de nulidade do contrato administrativo requererá análise prévia do interesse público envolvido, na forma do art. 147 desta Lei, e operará retroativamente, impedindo os efeitos jurídicos que o contrato deveria produzir ordinariamente e desconstituindo os já produzidos".

59 Todavia a Lei n. ${ }^{\circ}$ 14.133/2021 determina, mesmo para as situações em que a irregularidade for insanável, que a decisão da Administração sobre suspensão/nulidade do contrato somente seja adotada quando se revelar medida de interesse público (art. 147, (aput). Para tanto, a Administração deve considerar, em sua avaliação, os impactos econômicos e financeiros decorrentes do atraso na fruição dos benefícios do objeto do contrato (art. 147, I), os riscos sociais, ambientais e à segurança da população local decorrentes do atraso na fruição dos benefícios do objeto do contrato (art. 147, II), a motivação social e ambiental do contrato (art. 147, III), o custo da deterioração ou da perda das parcelas executadas (art. 147, IV), as despesas necessárias à preservação das instalações e dos serviços já executados (art. 147, V) e à desmobilização e ao posterior retorno às atividades (art. 147, VI), as medidas efetivamente adotadas pelo titular do órgão ou entidade para o saneamento dos indícios de irregularidades apontados (art. 147, VII), o custo total e o estágio de execução física e financeira dos contratos, dos convênios, das obras ou das parcelas envolvidas (art. 147, VIII), o fechamento de postos de trabalho diretos e indiretos em razão da paralisação (art. 147, IX), o custo para a realização de nova licitação ou celebração de novo contrato (art. 147, X) e o custo de oportunidade do capital durante o período de paralisação (art. $147, \mathrm{XI}$ ). Se, em vista desses elementos, verificar que a paralisação/anulação não se revela como medida de interesse público, a Administração deverá optar pela continuidade do contrato e pela solução da irregularidade por meio de indenização por perdas e danos, sem prejuízo da apuração de responsabilidade e da aplicação de penalidades cabíveis (art. 147, p. único). Dispondo desse modo, $o$ legislador admite que sejam sanadas (embora com consequências adicionais, como a indenização, a apuração de responsabilidades e a aplicação de penalidades) inclusive irregularidades que originalmente seriam insanáveis, porque resultam da prática de atos nulos. $\mathrm{O}$ instrumento por meio do qual um ato administrativo tem a sua regularidade sanada é a convalidação, qualificada por Celso Antônio Bandeira de Mello como "suprimento da invalidade de um ato com efeitos retroativos"; mas que apenas é admitida "quando o ato possa ser produzido validamente no presente", ou seja, quando "o vício não seja de molde a impedir reprodução válida do ato". MELLO, Celso Antônio Bandeira de. Curso de direito administrativo. 27. ed. São Paulo: Malheiros, 2010. p. 473-474. Sobre o assunto, ler também: MADUREIRA, Claudio. Licitações, contratos e controle administrativo: descrição sistemática da Lei n. ${ }^{\circ}$ 14.133/2021 na perspectiva do Modelo Brasileiro de Processo. Belo Horizonte: Fórum, 2021. p. 435-442.

${ }^{60}$ MADUREIRA, Claudio. Direito, processo e justiça: o processo como mediador adequado entre o direito e a justiça. Salvador: JusPodivm, 2014. p. 50-51.

${ }^{61}$ O princípio do contraditório sobressai do próprio texto constitucional, que assegura aos litigantes, em processo judicial ou administrativo, o contraditório e ampla defesa, com os meios e recursos a ela inerentes (CRFB, art. $\left.5^{\circ}, \mathrm{LV}\right)$, mas também encontra previsão no Código de Processo Civil de 2015, mais especificamente no seu artigo $7^{\circ}$, que confere às partes paridade de tratamento em relação ao exercício de direitos e faculdades processuais, aos meios de defesa, aos ônus, aos deveres e à aplicação de sanções processuais, impondo ao juiz zelar pelo efetivo contraditório, no seu artigo $9^{\circ}$, que proíbe a prolação de decisão contra uma das partes sem que ela seja previamente ouvida (direito de ser ouvido, que remete ao contraditório formal) e do inciso IV do parágrafo $1^{\circ}$ do seu artigo 489, que considera inadequadamente fundamentada a decisão que não enfrentar todos os argumentos deduzidos no processo capazes de, em tese, infirmar a conclusão adotada pelo julgador (direito de influir na resolução do problema, que remete ao contraditório material). Tamanha foi a preocupação do legislador processual em conferir semelhante caráter dialético ao modelo de
} 
da cooperaça ${ }^{62}{ }^{62}$. Com efeito, pode acontecer, ainda tendo em vista o exemplo anteriormente enunciado, de a sanatória do vício depreendido no ato praticado (convalidação) obstar o exercício do contraditório.

Imaginemos, ainda exemplificativamente, que a Administração tenha se esquecido de especificar no edital da licitação que a contratação almejada, voltada à execução de obra de engenharia de grande vulto, observará o disposto no artigo 102 da Lei n. ${ }^{\circ}$ 14.133/2021, que estabelece que “o edital poderá exigir a prestação da garantia na modalidade seguro-garantia e prever a obrigação de a seguradora, em caso de inadimplemento pelo contratado, assumir a execução e concluir o objeto do contrato" (cláusula de reto$\operatorname{mada}^{63}$ ). Uma vez apresentadas as propostas, a Administração, se tiver interesse em se beneficiar desse permissivo legal (a conclusão da obra pela seguradora certamente se apresenta como solução mais célere do que a realização de nova licitação), precisará republicar o edital, seja para que todos os licitantes tenham a oportunidade de retificar as suas propostas (de modo a adaptá-las ao cumprimento da exigência consistente na prestação de garantia na modalidade seguro-garantia) e reapresentá-las no curso do processo licitatório, seja para que outros prestadores possam avaliar a possibilidade de também participar do certame (tendo em vista, dessa feita, a sua nova conformação). A adoção desse cuidado é impositiva por força da conjugação da autorização normativa contida no artigo 147 da Lei n. ${ }^{\circ}$ 14.133/2021 (que possibilita a convalidação de atos praticados em processos de licitação e contratação pública como forma de atender ao interesse público) aos princípios processuais da instrumentalidade das formas (que admite a convalidação do ato, mas apenas quando não houver prejuízo aos interessados) e do contraditório (que impõe a republicação do edital, com a consequente reabertura do prazo para apresentação de propostas, de modo a que todos os interessados possam participar do certame e influir no seu resultado).

Todavia, pode acontecer, pelo menos no plano das cogitações, de licitantes cujas propostas originais comportaram garantia na modalidade de seguro-garantia com cláusula de retomada (Lei n. ${ }^{\circ}$ 14.133/2021, art. 102), e que por isso foram precificadas tendo em vista a apresentação dessa específica modalidade de garantia, pretenderem impugnar, em sede administrativa ou judicial, a republicação do edital (que possibilitaria a reapresentação de propostas por seus concorrentes), à consideração de que melhor atenderia à finalidade pública almejada (concluir a contratação, e com a garantia da fruição, pela Administração, da possibilidade de a seguradora terminar a obra) e (por conseguinte) o interesse público reclamado pelo artigo 147 da Lei n. $.^{\circ} 14.133 / 2021$, o aproveitamento das propostas anteriormente apresentadas que atenderem às especificidades exigidas no novo edital publicado, com o afastamento da possibilidade de reapresentação de propostas pelos licitantes que ofertaram outras modalidades de garantia e da apresentação de novas proposta por licitantes que não compareceram por ocasião do vencimento do prazo especificado no primeiro edital. A

processo adotado a partir da edição do código de 2015 que vedou aos julgadores a prolação de decisões sobre fundamentos (CPC2015, art. 10) e fatos (CPC-2015, art. 493, p. único) sobre as quais não se tenha dado ao interessados oportunidade de se manifestar, impondo-lhes que os ouçam antes de proferir decisão que os considere, de modo a que mesmo as razões que não foram deduzidas no processo precisem ser enfrentadas por quem decide.

${ }^{62}$ Por sua vez, o princípio da cooperação encontra assento no artigo $6^{\circ}$ da lei processual civil, que enuncia que todos os sujeitos do processo devem cooperar entre si para que se obtenha, em tempo razoável, decisão de mérito justa e efetiva. Esses princípios processuais (contraditório e cooperação) guardam íntima relação com a garantia do contraditório. Afinal, da conjugação entre eles resulta não apenas que os interessados na resolução do conflito devem dialogar para a obtenção de uma decisão justa (contraditório), mas, sobretudo, que devem fazê-lo cooperando entre si, como forma de contribuir para que a resolução do problema seja obtida de forma justa e efetiva, e em tempo razoável. A propósito, cf. (DIDIER JÚNIOR, Fredie. Os três modelos de direito processual: inquisitivo, dispositivo e cooperativo. DIDIER JÚNIOR, Fredie. Os três modelos de direito processual: inquisitivo, dispositivo e cooperativo. In: DIDIER JÚNIOR, Fredie et al. (coord.). Ativismo judicial e garantismo processual. Salvador: JusPodivm, 2013; ZANETI JÚNIOR, Hermes. CPC/15: o Ministério Público como instituição de garantia e as normas fundamentais processuais. Revista Jurídica da Corregedoria Nacional, v. 2, p. 101-166, 2017. Em sentido contrário MITIDIERO, Daniel. Colaboração no processo civil: pressupostos sociais, lógicos e éticos. 3. ed. São Paulo: Revista dos Tribunais, 2015. Sobre a dissenção entre os autores, PIMENTA, Henrique de Souza. A cooperação no CPC-2015: colaboração, comparticipação ou cooperação para o processo? 2018. Dissertação (Mestrado em Direito Processual) - Universidade Federal do Espírito Santo, Vitória, 2018. Disponível em: http://portais4.ufes.br/posgrad/teses/ tese_12175_Henrique\%20de\%20Souza\%20Pimenta.pdf. Acesso em: 9 set. 2021.

${ }^{63}$ Lei n. ${ }^{\circ}$ 14.133/2021. "Art. 99. Nas contratações de obras e serviços de engenharia de grande vulto, poderá ser exigida a prestação de garantia, na modalidade seguro-garantia, com cláusula de retomada prevista no art. 102 desta Lei, em percentual equivalente a até $30 \%$ (trinta por cento) do valor inicial do contrato" (grifos nossos). 
toda evidência, o deferimento desse pleito iria de encontro ao que prescreve o inciso XXI do artigo 37 da Constituição da República (que estabelece, entre outras coisas, que, "ressalvados os casos especificados na legislação, as obras, serviços, compras e alienações serão contratados mediante processo de licitação pública que assegure igualdade de condições a todos os concorrentes"), além de se contrapor aos princípios processuais da instrumentalidade das formas (porque o aproveitamento das propostas, nos moldes cogitados, traria prejuízos aos demais interessados) e do contraditório (porque nesse caso os demais interessados seriam impedidos de participar do processo licitatório e de influenciar no seu resultado). No entanto, soma-se a esses elementos normativos, a orientar a rejeição de hipotética impugnação administrativa ou judicial da republicação do edital, o princípio processual da cooperação, que, adaptado ao nosso objeto de análise, impõe aos licitantes que cooperem entre si para a obtenção das melhores condições de contratação pela Administração (finalidade pública), resultado que, entre nós, deve ser obtido, por taxativa opção constitucional (art. 37, XXI), por meio de ampla concorrência entre os interessados.

De igual modo podem ser operativos, nesse contexto, a extensão da vinculatividade do modelo de precedentes (que minimiza a configuração de dissensos sobre como o Direito deve ser aplicado nos casos concretos) e o desenvolvimento de atividade probatória (inclusive pela via da sua produção antecipada, quando isso se fizer necessário para a formação de consensos sobre a matéria fática $)^{64}$ à esfera administrativa, e a adoção, nesse contexto, do modelo decisório concebido pelo legislador processual (que confere maior transparência às tomadas de posição, minimizando as chances de que se configure, na casuística, a perpetuação de dissensos sobre a matéria fática e sobre como o Direito deve ser aplicado) ${ }^{65}$.

Enfim, a admissão, pelas razões dantes expostas, de que as licitações e contratações públicas são instrumentalizadas no curso de autênticos processos (compreendidos como procedimentos em contraditório), e não como simples procedimento (compreendidos como tão somente como sequência de atos voltados à produção de um resultado), confere aos intérpretes/operadores do Direito vasta gama de ferramentas jurídicas há muito aplicadas, no âmbito do Direito Processual Civil, para obter a flexibilização do rigor procedimental quando dele resulta embaraços à realização do direito material.

\section{5 À guisa de conclusão: licitações, contratos e controle administrativo}

Essas considerações, relativas à doutrina da processualidade do Direito Administrativo (segundo a qual o processo administrativo é o modo natural de atuação da Administração Pública ${ }^{66}$ ), à assimilação das suas premissas pela Lei n. ${ }^{\circ}$ 14.133/2021 (promovendo relevante mudança de paradigmas com relação ao regime normativo revogado) e à doutrina do formalismo-valorativo (que defende a flexibilização do formalismo processual como forma de possibilitar a realização do direito material deduzido no processo), orientam conclusão no sentido de que a utilização de ferramentas jurídicas extraídas do Modelo Brasileiro de Processo tem a funcionalidade de possibilitar a flexibilização do rigor procedimental a que se atribui a ineficiência das licitações e contratações públicas.

Porém, também é preciso atentar, nesse âmbito, a outro problema frequentemente relatado por contratantes e licitantes/contratados no mundo fenomênico como fator de desestímulo à ineficiência das aquisições públicas, consistente no relacionamento entre eles próprios (na condição de controlados) e os controladores, com destaque para a atuação do Ministério Público e dos Tribunais de Contas. O que em geral

\footnotetext{
${ }^{64}$ MADUREIRA, Claudio; ARAÚJO, Carlos André Luís; RODOR, Fernanda Medeiro e Riveiro. Autocomposição e ferramentas jurídicas. In: CAMPOS, Adriana Pereira et al. Perspectivas jurídicas: estudos em homenagem aos 30 anos de magistério de Francisco Vieira Lima Neto. Vitória: Edição dos Organizadores, 2021.

65 MADUREIRA, Claudio. Licitações, contratos e controle administrativo: descrição sistemática da Lei n. ${ }^{\circ}$ 14.133/2021 na perspectiva do Modelo Brasileiro de Processo. Belo Horizonte: Fórum, 2021. p. 70-83.

${ }_{66}$ Afinal, na lição de Cintra, Grinover e Dinamarco, o processo é instrumento para o legítimo exercício do poder e, por isso, está presente em todas as atividades estatais. CINTRA, Antonio Carlos de Araújo; GRINOVER, Ada Pellegrini; DINAMARCO, Cândido Rangel. Teoria geral do processo. 26. ed. São Paulo: Malheiros, 2010. p. 302.
} 
se denuncia nesse contexto é a configuração de irrefletida confusão entre erro jurídico e infração administrativa, a suscitar a responsabilização pessoal de agentes públicos e privados por simples divergência de interpretação jurídica ${ }^{67}$. Como decorrência disso, tornou-se cada vez mais difícil a atração, para ocupar posições de comando na gestão pública, de profissionais que se destacam por sua atuação anterior na iniciativa privada e/ou no meio acadêmico, que em muito poderiam contribuir para o aprimoramento da máquina administrativa.

Com efeito, são cada vez mais frequentes entre nós relatos de ex-gestores que se arrependem de ter atendido ao chamado da Administração, à consideração de que esse tipo de experiência, para além de os submeter a políticas remuneratórias pouco atrativas ${ }^{68}$ para profissionais de ponta ${ }^{69}$, ainda atrai o risco (muitas vezes concretizado) de precisarem responder, e com recursos próprios, pelos custos financeiros (a contratação de advogados envolve gastos significativos) e pessoais (inerentes ao abalo do seu conceito profissional na sociedade) de eventualmente virarem réus em ações de improbidade administrativa (em geral propostas pelo Ministério Público) e/ou em processos instaurados pelos Tribunais de Contas (controle externo) tão somente porque não foram capazes de antecipar, ao tempo da prática de atos concretos (muitas vezes embasados em pareceres jurídicos proferidos no âmbito o controle interno ${ }^{70}$ ) como os controladores sobre eles se posicionariam no futuro.

Esse estado de coisas de igual modo afeta o ambiente de negócios, visto que, como os agentes estatais, também os fornecedores do poder público e seus dirigentes podem ser alcançados pelos controladores, visto que o artigo $3^{\circ}$ da Lei de Improbidade Administrativa (Lei n. ${ }^{\circ}$ 8.429/1992) estende a aplicação das sanções nela previstas àqueles que, mesmo não sendo servidores/empregados públicos, induzam ou concorram para a prática do ato ímprobo ou que dele se beneficiem direta ou indiretamente. O que com isso queremos dizer é que a confusão entre erro jurídico e infração administrativa (por vezes depreendida no ambiente do controle administrativo) afeta os custos dos bens e serviços adquiridos, dada a incidência, também no ambiente privado, dos custos financeiros e pessoais/institucionais anteriormente referidos.

Abstraindo esse problema, embora sem excluí-lo do âmbito de nossas preocupações, também é fato que o rigor conferido pelo legislador (criticado por contratantes e licitantes/contratados, ainda que por razões distintas) jamais pareceu suficiente, sob a perspectiva dos controladores, a prevenir a contaminação de licitações e contratações públicas por atos de corrupção ou por desídia conducente à malversação de recursos públicos. É que a corrupção e a malversação de recursos em geral se associam (entre outras causas) ao superfaturamento dos preços dos bens e serviços adquiridos, que podem decorrer (inclusive) do direcionamento dos certames.

Ocorre que, mesmo sob esse enfoque a utilização de ferramentas processuais com o propósito de possibilitar a flexibilização do rigor procedimental atribuído pelo legislador às licitações e contratações públicas (nos moldes propostos neste trabalho) parece se apresentar como melhor saída para contratantes e licitantes/contratados. Afinal, da alternativa remanescente, consistente na manutenção desse rigor procedimental no ambiente administrativo, também poderá resultar, sob o ponto de vista dos controladores, infração ao

\footnotetext{
67 A propósito, a título de exemplo: BINENBOJM, Gustavo; CYRINO, André. O Art. 28 da LINDB: a cláusula geral do erro Administrativo. Revista de Direito Administrativo, Rio de Janeiro, ed. Esp., p. 203-224, 2018; MADUREIRA, Claudio. Limites e consequências da responsabilização de advogados públicos pareceristas por suas opiniões jurídicas. In: GAZOLA, Patrícia; CORREIA, Arícia Fernandes (org.). Advocacia pública municipal do século XXI. Rio de Janeiro: Ágora21, 2019; MADUREIRA, Claudio. Ilegitimidade da aplicação a agentes estatais de sanções fundadas em simples “erros jurídicos”. Revista Quaestio Iuris, v. 10, p. $2877-2903,2017$.

68 Porque os vencimentos/subsídios pagos aos agentes estatais estão sujeitos a teto remuneratório.

${ }^{69}$ Não tratamos, aqui, da tradicional estratégia de aparelhamento da Administração, que consiste na ocupação de cargos públicos por apadrinhados dos governantes eleitos ou de integrantes do seu grupo político, mas da contratação pelo poder público de pessoas que se destacam no mercado por sua formação acadêmica e/ou por sua experiência profissional.

${ }_{70}$ A propósito, recobramos que a Lei n. ${ }^{\circ}$ 14.133/2021 impõe a remessa do processo licitatório "o órgão de assessoramento jurídico da Administração" (leia-se: à Advocacia Pública) tão logo se encerre a sua fase de planejamento, para "controle prévio de legalidade mediante análise jurídica da contratação" (art. 53, caput), inclusive para efeito de manifestar sobre a juridicidade do edital de licitação (art. 53, p. $3^{\circ}$ ), e que essa atividade de controle jurídico é extensível a "contratações diretas, acordos, termos de cooperação, convênios, ajustes, adesões a atas de registro de preços, outros instrumentos congêneres e de seus termos aditivos” (art. 53, p. $4^{\circ}$ ).
} 
direito positivo, mais especificamente ao princípio administrativo da eficiência (CRFB, art. 37, caput), que se destina, na lição de Maria Silvia Zanella Di Pietro, a "alcançar os melhores resultados na prestação do serviço público" "71 e a imposição jurídico-normativa a que os agentes estatais não incorram em desvio de finalidade (Lei n. ${ }^{\circ} 4.717 / 1965$, art. $2^{\circ}$, "e"72), verificado, nos precisos termos da lei (Lei n. ${ }^{\circ}$ 4.717/1965, art. $2^{\circ}$, parágrafo único, "e"), quando eles praticam o atos visando fim diverso "daquele previsto, explícita ou implicitamente, na regra de competência" (que consiste, no caso específico das licitações e contratações públicas, na aquisição dos bens e serviços necessários à prestação de serviços públicos, e não na adoção de posturas conservadoras voltadas à sua proteção pessoal contra eventuais investidas dos controladores). Enfim, como disseram Antônio de Barros e Cecéu na letra da canção "Homem com H", por eles composta no início da década de 1979, mas celebrizada na voz de Ney Matogrosso em disco lançado em 1981, "se correr o bicho pega, se ficar o bicho come".

Disso resulta a pertinência da investigação, no plano da Ciência, sobre quais caminhos podem ser trilhados pelos intérpretes/aplicadores do Direito para que do exercício do controle administrativo (atividade importantíssima e que, ademais, é indissociável da atividade administrativa) não resultes embaraços ao desenvolvimento eficiente e eficaz dos atos praticados pela Administração, em especial daqueles relativos a licitações e contratações públicas, objeto de nossas preocupações neste trabalho. Quanto ao particular, recobramos que a Lei n. ${ }^{\circ}$ 14.133/2021 também disciplina o controle administrativo exercitado sobre os atos praticados nos processos de licitação e contratação pública ${ }^{73}$; o que vincula os controladores aos mesmos dispositivos legais que embasam a atividade desenvolvida pelos contratantes quando se relacionam com os licitantes contratados, trazendo maior previsibilidade e segurança ao relacionamento entre eles; e possibilita, ainda, a utilização de ferramentas próprias do Modelo Brasileiro de Processo para orientar a estruturação dessa atividade de controle ${ }^{74}$.

Posto isso, gostaríamos de, à guisa de conclusão, chamar a atenção para a imperiosa necessidade de que juristas (que atuam no plano da Ciência) e intérpretes (inseridos no campo da aplicação do Direito) voltem especial atenção para esse ponto. Afinal, se é verdade que os controladores estão submetidos, quanto às licitações e contratações públicas, às mesmas regras e princípios que disciplinam a atividade pública (a cargo dos contratantes) e privada (a cargo dos licitantes/contratados) desenvolvida pelos controlados, disso não resulta, por si só, a configuração, na prática, de relacionamento adequado e operativo entre eles. Esse relacionamento, que consideramos fundamental para a eficiência tanto das licitações e contratações públicas, quando do controle administrativo que sobre elas se estabelece com o propósito de combater atos de corrupção e a malversação de recursos públicos, precisa ser construído dia após dia, mediante esforço conjugado de controlados e controladores. Afinal, se os contratantes e licitantes/contratados (controlados) necessitam de maior segurança para desempenhar as suas atividades (consistentes, respectivamente, na seleção/contratação de fornecedores para a Administração e no fornecimento de bens e serviços para seus órgãos/entidades), também os controladores almejam ter a segurança de que do relacionamento entre contratantes e licitantes/contratados (controlados) não resultarão atos de corrupção/ malversação de recursos públicos.

De nosso ponto de vista, o caminho para alcançarmos esse objetivo não pode ser outro que não o do diálogo institucional; de igual modo aderente à proposta teórica sustentada neste trabalho, na medida em que pressupõe a substituição do ambiente de desconfiança que atualmente parece contaminar a relação entre controlados e controladores por um ambiente de efetiva cooperação, a demandar, de parte a parte, a plena observância ao princípio processual do contraditório (imposto pelo constituinte inclusive para os processos administrativos, entre

\footnotetext{
71 DI PIETRO, Maria Sylvia Zanella. Direito administrativo. 13. ed. São Paulo: Atlas, 2001.

${ }^{72}$ Lei n. ${ }^{\circ} 4.717 / 1965$. "Art. $2^{\circ}$ São nulos os atos lesivos ao patrimônio das entidades mencionadas no artigo anterior, nos casos de: a) incompetência; b) vício de forma; c) ilegalidade do objeto; d) inexistência dos motivos; e) desvio de finalidade" (grifos nossos).

73 MADUREIRA, Claudio. Licitações, contratos e controle administrativo: descrição sistemática da Lei n. ${ }^{\circ}$ 14.133/2021 na perspectiva do Modelo Brasileiro de Processo. Belo Horizonte: Fórum, 2021. p. 465-510.

${ }^{74}$ MADUREIRA, Claudio. Licitações, contratos e controle administrativo: descrição sistemática da Lei n. ${ }^{\circ}$ 14.133/2021 na perspectiva do Modelo Brasileiro de Processo. Belo Horizonte: Fórum, 2021.
} 
eles os processos de controle, e sem o qual não se cogita da configuração de diálogo entre os interessados na formação da decisão), ao princípio processual da instrumentalidade das formas (sem o qual não se cogita da realização do interesse público, ou do atendimento da finalidade pública, nos moldes reclamados pelo artigo 147 da Lei n. ${ }^{\circ}$ 14.133/2021) e ao dever de fundamentação adequada das decisões jurídicas, que impõe aos intérpretes/operadores do Direito, a formação de consensos sobre matéria fática (cujo esclarecimento demanda efetiva atividade probatória, a ser exercida, inclusive, mediante produção antecipada de provas) e sobre como deve se dar a aplicação do Direito (em muito facilitada pela adoção, entre nós, de um modelo de precedentes). No entanto, isso é assunto para outro estudo.

Por ora, apenas nos interessa chamar levantar o problema, seja pela via da apresentação da proposta teórica encartada neste trabalho, voltada à flexibilização do rigor procedimental conferido pelo legislador às licitações e contratações públicas (problema de pesquisa), seja por meio deste registro, que ora realizamos apenas à guisa de conclusão, de que é viável/necessária a extensão dessa proposta teórica também para a resolução do problema relativo ao relacionamento entre controlados e controladores (que também compromete, pelas razões dantes expostas, a eficiência das aquisições públicas). Com efeito, como disse Ronald Dworkin em O império do Direito, "quanto mais aprendemos sobre o Direito, mais nos convencemos de que nada de importante sobre ele é incontestável" ". Essa observação de Dworkin transporta para o ambiente jurídico conhecido aforismo atribuído a Sócrates, filósofo grego da Antiguidade, que, em vida, teria dito que (originalmente do latim) ipse se nibil scire id unum sciat (que significa, em tradução literal, "só sei que nada sei"), e que remete a conhecida máxima que governa o pensamento científico, que consiste em desconfiar das verdades absolutas (dogmas), porque elas criam obstáculo à ampliação das fronteiras da Ciência. Por esse motivo, longe de almejarmos apresentar respostas definitivas às indagações formuladas neste trabalho, ou construir única via interpretativa capaz de solucionar os problemas de que nos ocupamos, desejamos, em verdade, que essas nossas considerações sobre o tema possam suscitar, no futuro, questionamentos e debates tendentes à sua consolidação pela comunidade jurídica.

\section{Referências}

ÁVILA, Humberto. Repensando o princípio da supremacia do interesse público sobre o particular. In: SARMENTO, Daniel (org.). Interesses públicos versus interesses privados: desconstruindo o princípio da supremacia do interesse público. Rio de Janeiro: Lumen Juris, 2005.

ÁVILA, Humberto. Teoria dos princípios: da definição à aplicação dos princípios jurídicos. $4^{a}$ ed. São Paulo: Malheiros, 2005.

BEDAQUE, José Roberto dos Santos. Direito e processo. 4. ed. São Paulo: Malheiros, 2006.

BINENBOJM, Gustavo; CYRINO, André. O Art. 28 da LINDB: a cláusula geral do erro Administrativo. Revista de Direito Administrativo, Rio de Janeiro, ed. Esp., p. 203-224, 2018.

BRASIL JÚNIOR, Samuel Meira. Justiça, direito e processo: a argumentação e o direito processual de resultados justos. São Paulo: Atlas, 2007.

CAMPOS, Adriana Pereira et al. Perspectivas jurídicas: estudos em homenagem aos 30 anos de magistério de Francisco Vieira Lima Neto. Vitória: Edição dos Organizadores, 2021.

CARVALHO, Mateus. Manual de direito administrativo. 6. ed. Salvador: JusPodivm, 2019.

CINTRA, Antonio Carlos de Araújo; GRINOVER, Ada Pellegrini; DINAMARCO, Cândido Rangel. Teoria geral do processo. 26. ed. São Paulo: Malheiros, 2010.

\footnotetext{
${ }^{75}$ DWORKIN, Ronald. O império do direito. São Paulo: Martins Fontes, 1999. p. 13.
} 
CRETELLA JÚNIOR, José. Prática do processo administrativo. 6. ed. São Paulo: Revista dos Tribunais, 2008.

DALLARI, Adilson; FERRAZ, Sérgio. Processo administrativo. São Paulo: Malheiros, 2001.

DI PIETRO, Maria Sylvia Zanella. Direito administrativo. 13. ed. São Paulo: Atlas, 2001.

DI PIETRO, Maria Sylvia Zanella. Direito administrativo. 32. ed. Rio de Janeiro: Forense, 2019.

DIDIER JÚNIOR, Fredie et al. (coord.). Ativismo judicial e garantismo processual. Salvador: JusPodivm, 2013.

DIDIER JÚNIOR, Fredie. Curso de direito processual civil. 17. ed. Salvador: JusPodivm, 2015. v. 1.

DIDIER JÚNIOR, Fredie. Os três modelos de direito processual: inquisitivo, dispositivo e cooperativo. In: DIDIER JÚNIOR, Fredie et al. (coord.). Ativismo judicial e garantismo processual. Salvador: JusPodivm, 2013.

DINAMARCO, Cândido Rangel. A instrumentalidade do processo. 5. ed. São Paulo: Malheiros, 1996.

DINIZ, Maria Helena. Compêndio de introdução à ciência do direito: introdução à teoria geral do direito, à filosofia do direito, à sociologia jurídica e à lógica jurídica: norma jurídica e aplicação do direito. 20. ed. São Paulo: Saraiva, 2009.

DWORKIN, Ronald. O império do direito. São Paulo: Martins Fontes, 1999.

FAZZALARI, Elio. Instituições de direito processual civil. 8. ed. Campinas: Bookseller, 2006.

FAZZALARI, Elio. Istituzioni di diritto processuale. Padova: Cedam, 1975.

FERRAZ JUNIOR, Tércio Sampaio. Teoria da norma jurídica: ensaio de pragmática na comunicação normativa. 4. ed. Rio de Janeiro: Forense, 2009.

GAZOLA, Patrícia; CORREIA, Arícia Fernandes (org.). Advocacia pública municipal do século XXI. Rio de Janeiro: Ágora21, 2019.

JOBIM, Marco Felix. Cultura, escolas e fases metodológicas do processo. Porto Alegre: Livraria do Advogado, 2018.

JUSTEN FILHO, Marçal. Curso de direito administrativo. 12. ed. São Paulo: Revista dos Tribunais, 2016.

JUSTEN FILHO, Marçal. Curso de direito administrativo. 8. ed. Belo Horizonte: Fórum, 2012.

KELSEN, Hans. Teoria pura do direito. 7. ed. São Paulo: Martins Fontes, 2006.

LIEBMAN, Enrico Tullio. Manual de direito processual civil. 3. ed. São Paulo: Malheiros, 2005. v. 1.

LIMA, Rui Cirne. Princípios de direito administrativo. 6. ed. São Paulo: Revista dos Tribunais, 1987.

MADUREIRA, Claudio. A ciência jurídica e sua função social. Derecho y Cambio Social, v. 42, p. 01-12, 2015.

Disponível em: http://www.derechoycambiosocial.com/revista042/A_CIENCIA_JURIDICA_E_SUA_ FUN\%C3\%87AO_SOCIAL.pdf Acesso em: 01 set. 2021.

MADUREIRA, Claudio. Advocacia pública. 2. ed. Belo Horizonte: Fórum, 2016.

MADUREIRA, Claudio. Direito, processo e justiça: o processo como mediador adequado entre o direito e a justiça. Salvador: JusPodivm, 2014.

MADUREIRA, Claudio. Fundamentos do novo processo civil brasileiro: o processo civil do formalismo-valorativo. Belo Horizonte: Fórum, 2017.

MADUREIRA, Claudio. Ilegitimidade da aplicação a agentes estatais de sanções fundadas em simples "erros jurídicos”. Revista Quaestio Iuris, v. 10, p. 2877-2903, 2017.

MADUREIRA, Claudio. Licitaçoes, contratos e controle administrativo: descrição sistemática da Lei n. ${ }^{\circ}$ 14.133/2021 na perspectiva do Modelo Brasileiro de Processo. Belo Horizonte: Fórum, 2021.

MADUREIRA, Claudio. Limites e consequências da responsabilização de advogados públicos pareceristas 
por suas opiniões jurídicas. In: GAZOLA, Patrícia; CORREIA, Arícia Fernandes (org.). Advocacia pública municipal do século XXI. Rio de Janeiro: Ágora21, 2019.

MADUREIRA, Claudio. Recasens Siches e a aplicação do direito a partir da interação entre norma, fato e valor. Derecho y Cambio Social, n. 40, abr. 2015.

MADUREIRA, Claudio. Royalties de petróleo e Federação. Belo Horizonte: Fórum, 2012.

MADUREIRA, Claudio; ARAÚJO, Carlos André Luís; RODOR, Fernanda Medeiro e Riveiro. Autocomposição e ferramentas jurídicas. In: CAMPOS, Adriana Pereira et al. Perspectivas jurídicas: estudos em homenagem aos 30 anos de magistério de Francisco Vieira Lima Neto. Vitória: Edição dos Organizadores, 2021.

MADUREIRA, Claudio; ZANETI JÚNIOR, Hermes. Formalismo-valorativo e o novo processo civil. Revista de Processo, São Paulo, v. 42, n. 272, out. 2017.

MADUREIRA, Claudio; ZANETI JÚNIOR, Hermes. Processos estruturais e formalismo-valorativo. In: SICA, Heitor et al. (org.). Temas de direito processual contemporaneo: III Congresso Brasil-Argentina de Direito Processual. Serra: Milfontes, 2019. v. 2.

MARTINS, Ricardo Marcondes. Arbitragem e administração pública: contribuição para o sepultamento do tema. Interesse Público, v. 12, n. 64, p. 85-104, nov./dez. 2010.

MEDAUAR, Odete. A processualidade no direito administrativo. 2. ed. São Paulo: Revista dos Tribunais, 2008.

MEDAUAR, Odete. O direito administrativo em evolução. 3. ed. Brasilia: Gazeta Jurídica, 2017.

MELLO, Celso Antônio Bandeira de. Curso de direito administrativo. 27. ed. São Paulo: Malheiros, 2010.

MELLO, Celso Antônio Bandeira de. Curso de direito administrativo. 30. ed. São Paulo: Malheiros, 2013.

MITIDIERO, Daniel. Colaboração no processo civil: pressupostos sociais, lógicos e éticos. 3. ed. São Paulo: Revista dos Tribunais, 2015.

MITIDIERO, Daniel. Elementos para uma teoria contemporânea do processo civil brasileiro. Porto Alegre: Livraria do Advogado, 2005.

MITIDIERO, Daniel. Processo civil e estado constitucional. Porto Alegre: Livraria do Advogado, 2007.

MOREIRA NETO, Diogo de Figueiredo. Curso de direito administrativo. 16. ed. Rio de Janeiro: Forense, 2014.

NERY JÚNIOR, Nelson. Princípios do processo civil na Constituição Federal. 7. ed. São Paulo: Revista dos Tribunais, 2002.

OLIVEIRA, Carlos Alberto Alvaro de. Do formalismo no processo civil. 3. ed. São Paulo: Saraiva, 2009.

OLIVEIRA, Carlos Alberto Alvaro. O formalismo-valorativo no confronto com o formalismo excessivo. Gênesis: Revista de Direito Processual Civil, v. 11, n. 39, p. 15-36, jan./jun., 2006.

PIMENTA, Henrique de Souza. A cooperação no CPC-2015: colaboração, comparticipação ou cooperação para o processo? 2018. Dissertação (Mestrado em Direito Processual) - Universidade Federal do Espírito Santo, Vitória, 2018. Disponível em: http://portais4.ufes.br/posgrad/teses/tese_12175_Henrique\%20 de\%20Souza\%20Pimenta.pdf. Acesso em: 9 set. 2021.

REALE, Miguel. Lições preliminares de direito. 24. ed. São Paulo: Saraiva, 1998.

SARMENTO, Daniel (org.). Interesses públicos versus interesses privados: desconstruindo o princípio da supremacia do interesse público. Rio de Janeiro: Lumen Juris, 2005.

SUNDFELD, Carlos Ari. (org.). Contratações públicas e seu controle. São Paulo: Malheiros, 2013.

SUNDFELD, Carlos Ari. Como reformar as licitações? In: SUNDFELD, Carlos Ari (org.). Contratações públicas e seu controle. São Paulo: Malheiros, 2013. 
ZANETI JÚNIOR, Hermes. CPC/15: o Ministério Público como instituição de garantia e as normas fundamentais processuais. Revista Jurídica da Corregedoria Nacional, v. 2, p. 101-166, 2017.

ZANETI JÚNIOR, Hermes. Direito material e direito processual: relações e perspectivas. Revista Processo e Constituição - Cadernos Galeno Lacerda de Estudos de Direito ProcessualConstitucional, Porto Alegre, v. 1, p. 245-278, 2004.

ZANETI JÚNIOR, Hermes. Processo constitucional: o modelo constitucional do processo civil brasileiro. Rio de Janeiro: Lumen Juris, 2007. 
Para publicar na revista Brasileira de Políticas Públicas, acesse o endereço eletrônico www.rbpp.uniceub.br

Observe as normas de publicação, para facilitar e agilizar o trabalho de edição. 